\title{
Walrus history around the North Water: Human-animal relations in a long-term perspective
}

\author{
Anne Birgitte Gotfredsen, Martin Appelt, Kirsten Hastrup
}

Published online: 7 March 2018

\begin{abstract}
This article highlights the relationship between walruses and humans in and around the North Water polynya in a long-term perspective. The present study draws on a combination of biological, archaeological, archaeo-zoological, historical, and ethnographic sources covering the period from the 8th century $\mathrm{AD}$ to the late 20th century. The study demonstrates that the walrus was an important resource of meat, blubber, and other products throughout all the studied periods, if always supplemented by other kinds of game. It is suggested that walrus distribution and behaviour, as well as hunting strategies and technologies historically constituted a powerful component not only in forming human action and social life in the region but also in serving as an imaginative resource. It is further argued that the walrus and the walrus hunt still play a significant role in the present community living on the edge of the North Water, even if the hunt is increasingly circumscribed due to changing ice conditions.
\end{abstract}

Keywords Archaeo-zoology · Atlantic walrus ·

Communal hunting · North Water polynya .

Odobenus rosmarus rosmarus · Prehistoric sites

\section{INTRODUCTION}

In this paper, we explore the role of the Atlantic walrus (Odobenus rosmarus rosmarus) in the region around the North Water polynya (Pikialasorsuaq). The walrus has contributed significantly to the entire socio-ecological system in the region in shaping both the hunting economy and people's aspirations, and offering up a rich source of meat and blubber-for people as well as dogs - of hides, ivory and imaginations through the ages. (e.g. Vibe 1950; Born 1987; Born et al. 1995, 2017 and references therein).
The walrus also has its own history, so to speak-both in a long-term perspective (see Born 2005) and possibly from a shorter term perspective of change in overall distribution and movements (e.g. Stewart et al. 2014), and in its response to climate and hunting practices (e.g. Born 1987; Born et al. 2017). Both these time-scales impinge upon the human-animal relationships that are at the centre of this article.

More specifically, the article analyses the significance of the walrus as an agent in the economy, the social life, and the imageries of the hunting communities that have settled in the area through the ages. Even today, and in spite of increasingly difficult access due to changing movement patterns induced by climate change, walrus forms an important component of Inughuit hunting (Born et al. 2017), embodying the varied aspirations of people living both inside and outside Avanersuaq (the 'big North'), often referred to as the Thule Region since early 20th century. As such the walrus has also become a site of contestation, some hunters insisting on their unlimited rights of access and on the sustainability of the traditional hunt, and marine biologists and management bodies wishing to ensure the long-term viability of walrus populations and walrus hunting on the basis of scientific measurements of the stock (e.g. NAMMCO 2006, 2010; Witting and Born 2014; Born et al. 2017).

This article includes the results of new archaeological surveys and archaeo-zoological finds from the Thule Region as well as a reassessment of previous archaeological and historical sources. Based on this evidence and by including historical documentation we seek to understand how, when, and why the walrus has become emblematic in the perception of both the riches and the challenges of the living resources upon which social life in this High Arctic region always depended. The geographical emphasis is on 
the North Water region, which corresponds to the distribution of the northern Baffin Bay walrus stock as defined (NAMMCO 2010; Andersen et al. 2014; Stewart et al. 2014), in combination with the maximum extent of the lands that historically were used by people living in the North Water area, i.e. the sea ice- and landscape surrounding the North Water polynya from the tip of Cape York (Innaanganeq), north to Washington Land, across to the eastern coast of Ellesmere Island (Umingmak Nuna) and south to Cape Faraday (Fig. 1a, b). Comparisons will be made to relevant archaeological, historical and archaeozoological sources from the Foxe Basin, Central Canadian Arctic, and North East Greenland.

\section{WALRUS LIFE HISTORY, ECOLOGY, AND DISTRIBUTION}

Walruses are highly gregarious pinnipeds that tend to travel in small groups and haul out on ice or on land to rest, moult and bearing their young (Fay 1982). They inhabit the moving pack ice, or drift ice, and areas with thin-ice where they are capable of breaking through up to $20 \mathrm{~cm}$ thick ice and maintaining holes in even thicker ice. Although walruses may feed on a variety of bottom-dwelling invertebrates, only a few bivalves-usually Mya sp., Hiatella sp. and Serripes sp.-make up the bulk of their diet (Vibe 1950; Born 2003).

Recent assessments on walrus foraging behaviour in Smith Sound concluded that most dives for food were $<100 \mathrm{~m}$ [although much deeper dives were observed (Garde et al. 2018)], which coincided well with the bathymetric distribution of walrus preferred prey items i.e. the saltwater clams of the genera Mya and Hiatella (Vibe 1950). The patchy distribution of walrus is thus largely governed by ice coverage and thickness in combination with prey distribution (Born 2005). As most polynyas including the North Water have light see ice conditions during winter and shallow water banks with suitable walrus food, the walrus is a typical 'polynya animal' (Born 2005). This makes walruses an important and geographically predictable stable food and raw material source for the Inuit/Inughuit.

Sexual maturity is reached fairly late. For Atlantic walruses in the North Water the mean age of attainment of sexual maturity is c. 6 years of age in females and c. 11 years in males (Born 2001, 2003); the reproductive cycle is basically triennial with females giving birth every 3 years and the calf staying with its mother for at least 2 years (Born 2001). Generally, the capacity for population growth is considered to be relatively low (e.g. Born et al. 1995 and references therein), although annual maximum population growth rate up to $7-8 \%$ per year has been documented (Kovacs et al. 2014). In addition, walruses are vulnerable to environmental changes (e.g. Laidre et al. 2008), although it is disputed how and to what extent especially Atlantic walruses may be affected by climate change (cf., Born 2005; Born et al. 2017). Due to their restricted distribution walruses are relatively easy to hunt (Born et al. 1995, p. 9).

Presently, and presumably in former times, walruses together with belugas (Delphinapterus leucas), narwhals (Monodon monoceros), bearded seals (Erignathus barbatus) and ringed seals (Phoca hispida) winter in the general region of the North Water polynya, a large part of them in the eastern part of the polynya along the Greenland shores (Born et al. 2004; Heide-Jørgensen et al. 2016). During the open-water period in summer, the walrus distribution is more restricted and primarily confined to the eastern coast of Ellesmere Island, Canada. Walruses are therefore virtually absent during the open-water season in Greenland waters for a couple of months, except for a few stragglers (Stewart et al. 2014; Born et al. 2017, 56ff). In the North Water area, walruses are segregated on the basis of sex and age class, with females and calves to be found farther north than adult males (Vibe 1950; Born et al. 2017).

Walrus research from the last couple of decades has clearly demonstrated that in historic as well as modern times human societies have heavily influenced walrus populations, in terms of changed migration routes, population size reduction perhaps affecting population structure, and a shift in the distribution of the sex-segregated groups (e.g. Born et al. 1994, 1995; Wiig et al. 2007, p. 74; Witting and Born 2014). However, most recent studies indicate signs of recovery of the walrus subpopulation that are harvested in the North Water area (Witting and Born 2014). In the first half of the 20th century, there was allegedly an influx of walruses into the North Water from the south during June and July (Freuchen 1921; Vibe 1950). Recent aerial surveys could not confirm this migration pattern, however, which implies that migration routes may have shifted, as may the timing of migration (Born et al. 1994, 1995, 2017). Around the beginning of the 20th century, a terrestrial haul-out site, an ulli, at Littleton Island (Pikiuleq) and on the shore opposite the island still existed (Hayes 1867; Peary 1917; Freuchen 1921); in addition, Vibe was told in 1939-1940 about two haul outs in the Wolstenholme Fjord by a local hunter (Vibe 1950). The terrestrial haul outs on the Greenlandic side of the North Water are now all abandoned (Born et al. 1995, p. 52, 2017).

While the ringed seal constituted the cornerstone in subsistence of all prehistoric human populations in coastal Greenland, Arctic Canada, and Alaska (e.g. Murray 1996, 1999; Woollet et al. 2000), walrus was hunted and exploited by all coastal Inuit groups as well as their 

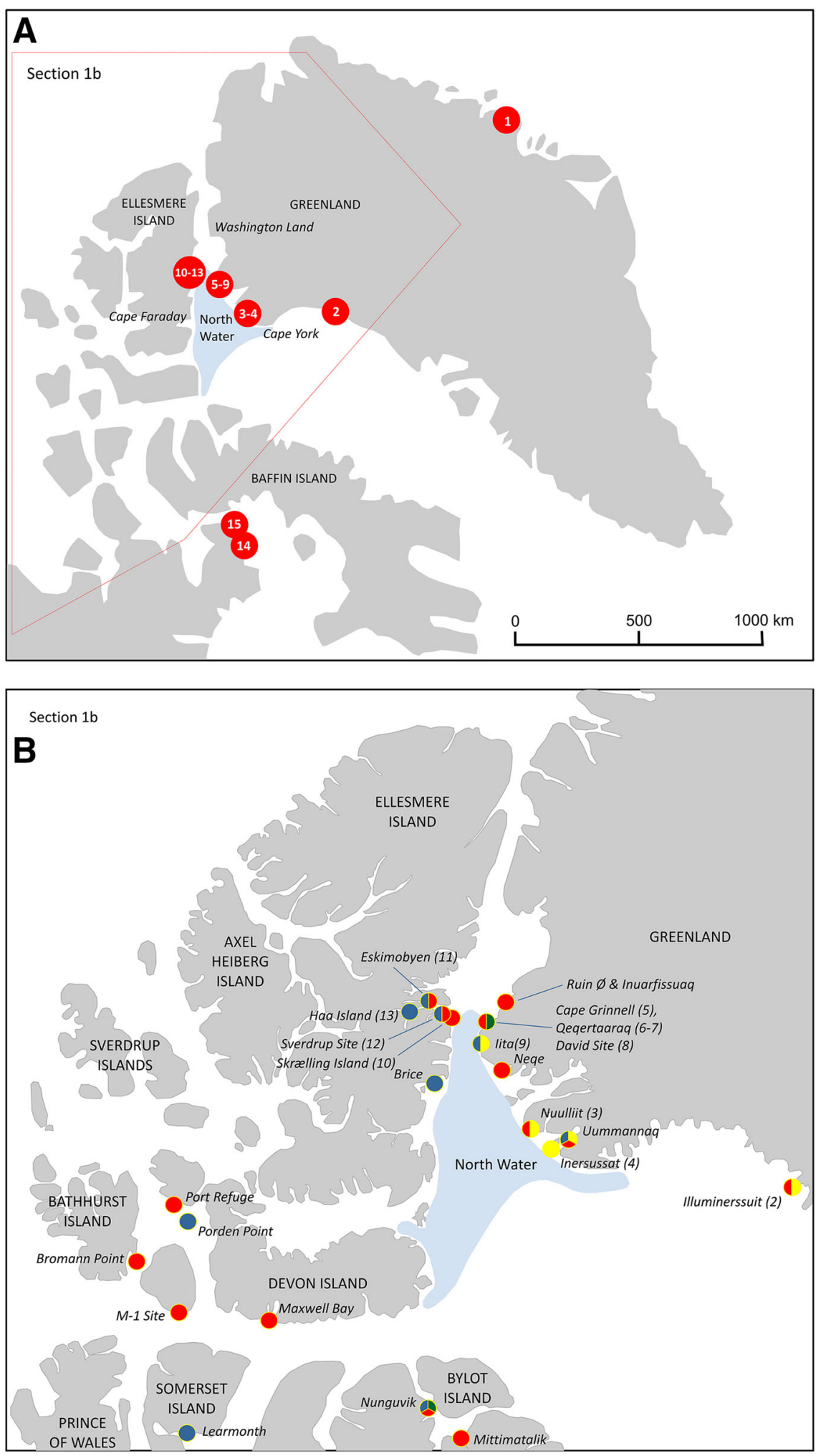

Fig. 1 a Important archaeological sites mentioned in the text: (1) Hvalros $\emptyset$, (2) Illuminerssuit, (3) Nuulliit, (4) Inersussat, (5) Cape Grinnell, (6) SW-Point (Qeqertaaraq), (7) Walrus site (Qeqertaaraq), 8) David site, (9) Iita, (10) Skrælling Island, (11) Eskimobyen, (12) Sverdrup site, (13) Haa Island, (14) Sanirajak, (15) Alarnerk and the Igloolik Island. Numbers 1-14 refer to numbers in Table 1. Drawing: M. Appelt. b Important sites and their cultural components. Green dots $=$ sites with late Dorset component, Red dots $=$ sites with ruin Island-phase Inuit component, Blue dots $=$ sites with post-Ruin Island-phase, Inuit component, and Yellow dots $=$ Sites with Inughuit/Inuit component. Multi-colour dots indicate presence of more than one component on the site. Numbers in brackets correspond with numbers in (a). Drawing: M. Appelt 
predecessors, although with varying intensity and in different ways at different periods. The ubiquitous ringed seal is accessible year round, whereas walruses and other large marine and terrestrial mammals have a more restricted distribution spatially and seasonally, and thus a varied accessibility. Ringed seal can be hunted, easily managed and transported by a single hunter. In contrast, the much larger walrus can be aggressive and will attack kayaks and umiat (open skin boats), or chase hunters through thin-ice from beneath; furthermore walrus females will protect their young with vigour (Nelson 1969, p. 363; Freeman 1975, p. 150; Fay 1982; Born et al. 2017). In other words hunting walrus for the hunter posed a high risk of becoming injured or even killed. Through a communal hunting strategy the risk of the individual hunter was minimised; along with the communal hunt a sharing system of the game developed within the community, distributing the meat more or less equally (e.g. Holtved 1967, pp. 116-122). Moreover, the fluctuating accessibility over the year warranted a welldeveloped storing system (e.g. Murray 1999, p. 476).

Basically, there are (and were) four ways of hunting walrus: First, hunting on thin-ice, while the ice is still so thin that the walrus can break through it to breathe and be harpooned by the hunter. This kind of hunt was practiced in early winter and in spring, although sometimes hampered or impeded when the snow cover became too thick (e.g. Vibe 1950; Born et al. 2017). Second, there is the hunting in pack ice, where walruses may haul out, and third, there was a hunting in open water from kayak (now motor-boat), performed during summer and early autumn. Finally, in regions where terrestrial haul-out sites were present the walruses were also targeted there (Born et al. 2017). While things have certainly not been 'the same' through the centuries, there are remarkable continuities, as we shall show in the following sections.

\section{MATERIALS AND METHODS}

The archaeological and archaeo-zoological source material from the Greenlandic side of the North Water is substantial, reflecting 80 years of changing excavation practices. During the periods 1935-1937 and 1946-1947 Holtved (1944a, b, 1954) undertook the first systematic large-scale excavations in the area. In spite of excellent preservation conditions in the High Arctic, Holtved did not recover faunal remains (except for tool implements of organic matter). During the last couple of decades, Holtved's work has been supplemented through excavation campaigns in 1996 and 1997 by the 'Gateway to Greenland' project at Hatherton Bay, Inglefield Land, which for the first time encompassed the collection of faunal material from the area, i.e. from four Late Dorset sites (Appelt and Gulløv
1999; Christensen 2000). Through archaeological surveys and excavations since the 1990s the ILAP (Ingefield Land Archaeological Project) project provided substantial new information and artefactual materials from both Late Dorset and Early Thule culture sites (Darwent et al. 2007, 2008; Darwent and Foin 2010; Darwent and Johansen 2010; LeMoine and Darwent 2010; Johansen 2013). Finally, the NOW Project 2014-2017 obtained new data on walrus exploitation from excavations at the classic Nuulliit site from midden layers in front of a qassi (a Men's house) combined with comprehensive surface registrations of animal bones on sites in the Innaanganeq and the Pittufik area (Grønnow et al. 2015, 2016, 2017; Mønsted 2016). On the Canadian side of the North Water polynya extensive archaeological field-campaigns have been conducted since the 1970s notably in the central parts of eastern Ellesmere Island, covering all periods of the human history in the area. Both the archaeological and archaeo-zoological material from Ellesmere Island is very well-published and constitutes the central frame of reference for all of the North Water (McCullough 1989; Schledermann 1996; Schledermann and McCullough 2003).

Regarding the archaeo-zoological quantification methods the animal bones were quantified by NISP (number of identified specimens), which is normally considered the basic unit to measure taxonomic abundance among archaeo-zoological assemblages (e.g. Lyman 1996). Further the MNI (minimum number of individuals) were calculated in order to make the biomass [or TBM (total body mass)] estimations. The species identified and quantified walrus abundance, as expressed by NISP excluded the debitage, i.e. small splinters and fragments of tusk, penis bone (baculum), mandibles and maxillary bone resulting from tool production and tusk extraction, in order to make the number of walrus fragments comparable to the other game animals.

In addition to the prehistoric source material, this article also incorporate historical reports and archival material as well as more recent ethnographic sources. When it comes to the methods involved in analysing this follows wellestablished procedures for contextual interpretation and cross-cultural (or cross-temporal) comparison based on positive knowledge. In turn, such interpretive efforts widens the possible analysis also of prehistoric conditions, and allows for a more general conclusion of the walrus as a principal resource for humans, both past and present.

\section{THE IMPORTANCE OF WALRUS IN PREHISTORY}

The prehistory of the North Water walrus hunting cannot be understood without including a wider geographical perspective. Therefore we include zoo-archaeological 
material from Foxe Basin, Central Canadian Arctic, where walruses form a stable year-round source (e.g. Born et al. 1995). The earliest specific cultural adaptations of walrus hunting is likely to have taken place among pre-Inuit Dorset groups in the Foxe Basin region (Murray 1996, 1999). The continued importance of the walrus hunting in the Foxe Basin is illustrated by including, for instance, the Ruin Island-phase site of Sanirajak (Desjardins 2013), which in several aspects resembled the abovementioned Nuulliit site. We will furthermore make reference to the post-Ruin Island archaeological record from Hvalros $\varnothing$ (North East Greenland), as well as the newly analysed archaeological record from the Ruin Island-phase site of Illuminerssuit [Kap Seddon, Eastern Melville Bay (Qimusseriarsuaq)].

Dyke et al. (1999) examined walrus records across Arctic and Atlantic Canada and concluded that walrus remains occurred in scarce numbers in assemblages dating to early pre-Inuit cultures the so-called 'Arctic small tool tradition' or AST (Saqqaq, Independence, and Pre-Dorset) c. 2400-500 вс. They also concluded that walrus remains consisted primarily of debitage and not 'diet-related' remains (Dyke et al. 1999, 173f). On the Greenlandic shores of the North Water early pre-Inuit cultures are only sporadically evidenced and the meagre sites are devoid of preserved organic material (e.g. Sørensen 2010). The first substantial evidence of extensive walrus hunt in the eastern Arctic was seen among pre-Inuit Dorset groups (500 BC$500 \mathrm{AD}$ ) in the Igloolik area (Fig. 1a, no. 15), Canadian Foxe Basin (Murray 1996, 1999). An increase in the relative importance of walrus hunting (Murray 1999: Fig. 5; see also Dyke et al. 1999: Table 5) resulted in Dorset dwellings and their associated middens being considerably more substantial and numerous than the ruins of their predecessors (i.e. pre-Dorset cultures). This allowed for an increase of human population and a more sedentary life (Murray 1996, 1999). Interestingly, communal hunting activity was evidenced by an increase in walrus hunting harpoon heads being decorated, probably marking ownership of game and facilitating the relationships between hunters and their sharing of the walrus (Murray 1999, 474f). The Pre-Inuit Late Dorset sites located at the edge of the North Water (c. 700-1300 AD) exhibited a similar pattern, i.e. with heavier dwelling structures and deeper middens, likely the result of less mobility in the area, with (communal) walrus hunting playing an important role in the economy, social organisation and worldview (Schledermann 1990; Appelt and Gulløv 1999; Christensen 2000).

Generally, the long-term history of human presence in the NOW-area is punctuated, with periods of possibly 200-500 years of continuous presence succeeded by periods ranging from 100 to 1000 years with limited occasional or no human presence in the area (Figs. 1a, b, 2). In the following paragraphs all dates are given in calibrated dates unless otherwise stated. In the present context, the chronological starting point is defined by the pre-Inuit Late Dorset (sometimes known as Tunit) groups' settling around the North Water sometime during the 8th century AD. The presence of Late Dorset groups in the area seems to have been more or less continuous until their disappearance during the late 13th century $\mathrm{AD}$ (e.g. Appelt and Gulløv 2009). This happened synchronously with and partly connected to, the earliest Bering Strait Inuit moving into the eastern Arctic sometime in the 13th century AD (Friesen and Mason 2016; see also Hastrup et al. 2018). The early phase is known as the Ruin Island-phase; its geographical extent is not entirely clear, but by the 14th century AD Inuit sites are well-established from the northern Melville Bay north to Hall Land and along the central part of eastern Ellesmere Island (Holtved 1944a, b, 1954; McCullough 1989). The architectural layout and the archaeological assemblages uncovered from the 10 known Ruin Islandphase Inuit sites in the NOW-area (Fig. 1b) clearly indicate that communities were organised around communal hunting of baleen whales and walrus, headed by the umiaq owners - the umialik - architecturally manifested in the socalled Men's house and likely involving crews from all households in the villages (e.g. Savelle 2002; Mønsted 2016).

From the early 15 th century a considerable part of the human population probably moved out of the NOW-area and settled in North East Greenland (Sørensen and Gulløv 2012). At the same time, or perhaps beginning a century earlier, other Inuit groups moved south and settled in all the coastal areas south of the Melville Bay, while some moved northeast and down south again along the East Greenlandic coast (Gulløv 2004). In the following, the Inuit settlements in the NOW-area from the middle of the 15th century until the early 17th century will be referred to as the post-Ruin Island-phase. After mid-15th century AD there is no evidence of Men's houses still in use in the NOW-area and only limited evidence for hunting of large whales and for the use of the umiaq. It is likely that the umialik-institution was dissolving in the beginning of the post-Ruin Islandphase.

The walrus hunt seems to have continued to play a crucial role during the post-Ruin Island-phase; even if there is no direct evidence of a communal hunt, it was most likely the case given the strength needed for manoeuvring the huge animal. While the richness of the North Water ecosystem was capable of supporting an Alaskan lifestyle of early Inuit groups for a couple of centuries, based equally on whale and walrus hunting, it collapsed during the 14th-15th century. Archaeological sites dated to the 16 th and 17th centuries are few in the NOW-area and probably the human population in the area was at a very 


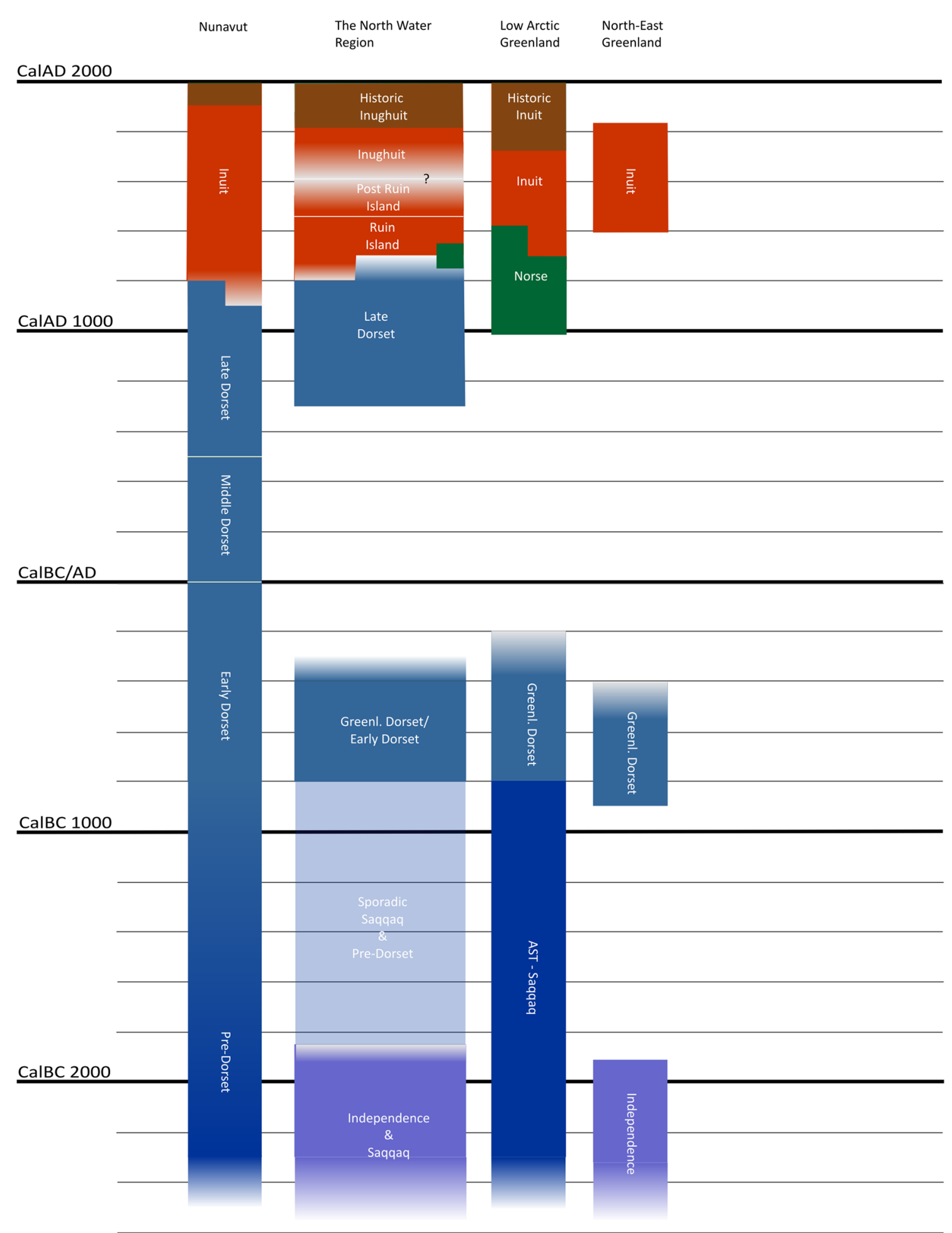

\section{CalBC 3000}

Fig. 2 The chronological framework. Modified after M. Appelt in Maanasa et al. (2014) 
low level during these centuries (Schledermann and McCullough 2003). The few known sites, such as Iita (or Etah), are found at locations with direct access to stable and predictable hunting, e.g. of little auk (Alle alle) colonies, Arctic fox (Alopex lagopus), and walrus (LeMoine and Darwent 2016). The expansion of the Inuit population in the larger Thule area is likely to have taken place in the 18th century AD (Schledermann and McCullough 2003).

In order to trace back in time the significance of walrus hunting in the North Water area based on the archaeological evidence a number of faunal bone assemblages were studied (Fig. 1a, b and Table 1). Walrus abundance as measured by NISP counts varied greatly across the studied sites and across the chronological periods (Table 2 and Fig. $3 \mathrm{a}-\mathrm{c}$ ). It is, however, important to note that not all sites were directly comparable due to a variable number of archaeological structures, e.g. middens, turf-houses and meat caches, at each site and therefore of variable sample sizes (see Tables 1, 2).

At the pre-Inuit Late Dorset sites walrus comprised between 10 and $72 \%$ of the mammals with the Hatherton Bay sites (nos. 6-8) varying between 25 and $72 \%$. This is quite a substantial amount of walrus compared to other High Arctic Late Dorset samples reported to amount to less than 5\% (e.g. Darwent and LeMoine 1998; Schledermann 1990). At the Ruin Island-phase Inuit sites walrus comprised between 2 and $49 \%$ with the Sanirajak site (no. 14) in Foxe Basin, Central Canadian Arctic amounting to c. $49 \%$, whereas the remainder varied between 2 and $21 \%$. Finally at the post-Ruin Island-phase Inuit sites including the Inughuit period walrus varied between 2 and $85 \%$. However, by leaving out Inersussat on Saunders Island (Appat) and Hvalros $\varnothing$, North East Greenland, the post Ruin Island-phase sites varied between 2 and 10\%. Saunders Island was contemporary with the sites of Neqe and Pitoqavik and known as focal places for walrus hunting, also in historical times (Vibe 1950; Grønnow 2016 and references herein; Born et al. 2017). Besides being pivotal places for walrus hunting Inersussat at Saunders Island and Hvalros $\varnothing$ situated by another recurring polynya the Sirius Water, East Greenland (Gotfredsen 2010; Grønnow et al. 2011) were recorded in the same way by surface in situ registration and hence differently from the remainder of sites. This surface registration method may have affected the recorded high relative importance of walruses.

Through all the studied cultural periods the walrus ranked between 1 and 4 in the archaeo-zoological assemblages, as expressed by NISP based abundance, except for the post Ruin Island-phase Haa Island site (no. 13) where it ranked 6 (Table 3). Small seals, almost exclusively consisting of ringed seal, formed the staple resource and ranked 1 in terms of NISP as well as MNI at the majority of sites. For instance, at the Eskimobyen site MNI of small seals varied between three and 32 among the excavated structures $(n=9)$, whereas walrus varied between one and five (Schlederman and McCullough 2003). However, when one accounts for the amount of meat, blubber and other products such as hide and tusk provided per walrus the importance shifted in favour of walrus and other large sized marine mammals (see also Gotfredsen 2010). Adult females of Atlantic walruses reach an average total body mass (TBM) of 700-800 kg (Knutsen and Born 1994), whereas male reach a TBM of $1100-1200 \mathrm{~kg}$, some may even reach $1600 \mathrm{~kg}$ (Knutsen and Born 1994; Born and Aquarone 2007) opposed to the adult ringed seal reaching c. $55 \mathrm{~kg}$ (Born and Böcher 2001). At the qassi midden on the Nuulliit site (no. 3) the distribution of the species identified mammals clearly illustrates to which extent the large sized marine mammals contributed to the (food) economy when quantified in terms of biomass as expressed by the total body mass (TBM) opposed to NISP (Fig. 4ac). How much the various species actually contributed to the food economy is difficult to estimate. There may have been a considerably seasonal and inter-annual variability. Born (1987) estimated that walrus annually provided c. $25 \%$ of edibles mainly from open-water hunting in the Thule area. Estimations were based on information gathered from hunters of the Thule area between 1977 and 1985 (Born 1987). The estimated amount of biomass contributed by bowhead whales (Balaena mysticetus) was left out of the calculations since it would have completely overshadowed the importance of other species. Still, the remains of at least four individual bowhead whales were present at the Nuulliit peninsula all of which were presumed to belong to the Ruin Island-phase. One of the skulls located adjacent to the excavated qassi midden was radio-carbon dated to $1302 \pm \mathrm{BP}$ (AAR-24771) and thus dated to $\mathrm{AD}$ 1056-1143 (1 Sigma range; $\delta 13 \mathrm{C}=-14.49 \pm 0.23$ ) (Stuiver and Reimer 1993). Due to variability in the marine correction reservoir age we consider the bowhead skull to be contemporary with the habitation of the site. ${ }^{1}$ Given that all bowheads were contemporary they would have contributed massively to the resource influx of the Ruin Island population.

Information on the sex and age distribution of the hunted walruses is crucial knowledge since the demographic profile of the catch influences productivity of the walrus

\footnotetext{
${ }^{1}$ Marine materials are notoriously difficult to radio-carbon date, and in particular whale bone poses a challenge. Using the standard marine correction reservoir age of 400 years the death of the whale seems to have taken place a century or two prior to the use of the qassi. A broader marine correction reservoir age (see e.g., Dumond and Griffin 2002, Table 2) would have implied contemporaneity between the bowhead whale cranium and the Nuulliit qassi.
} 


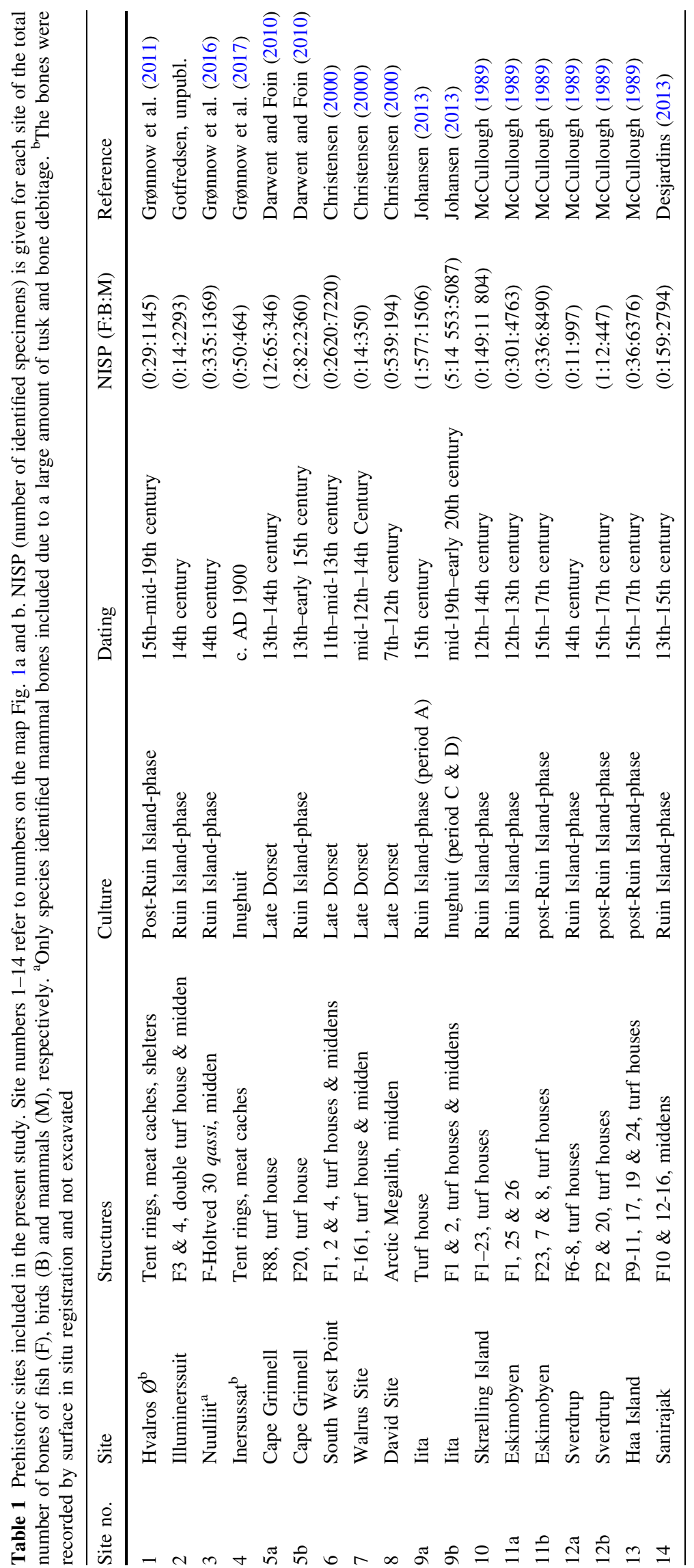




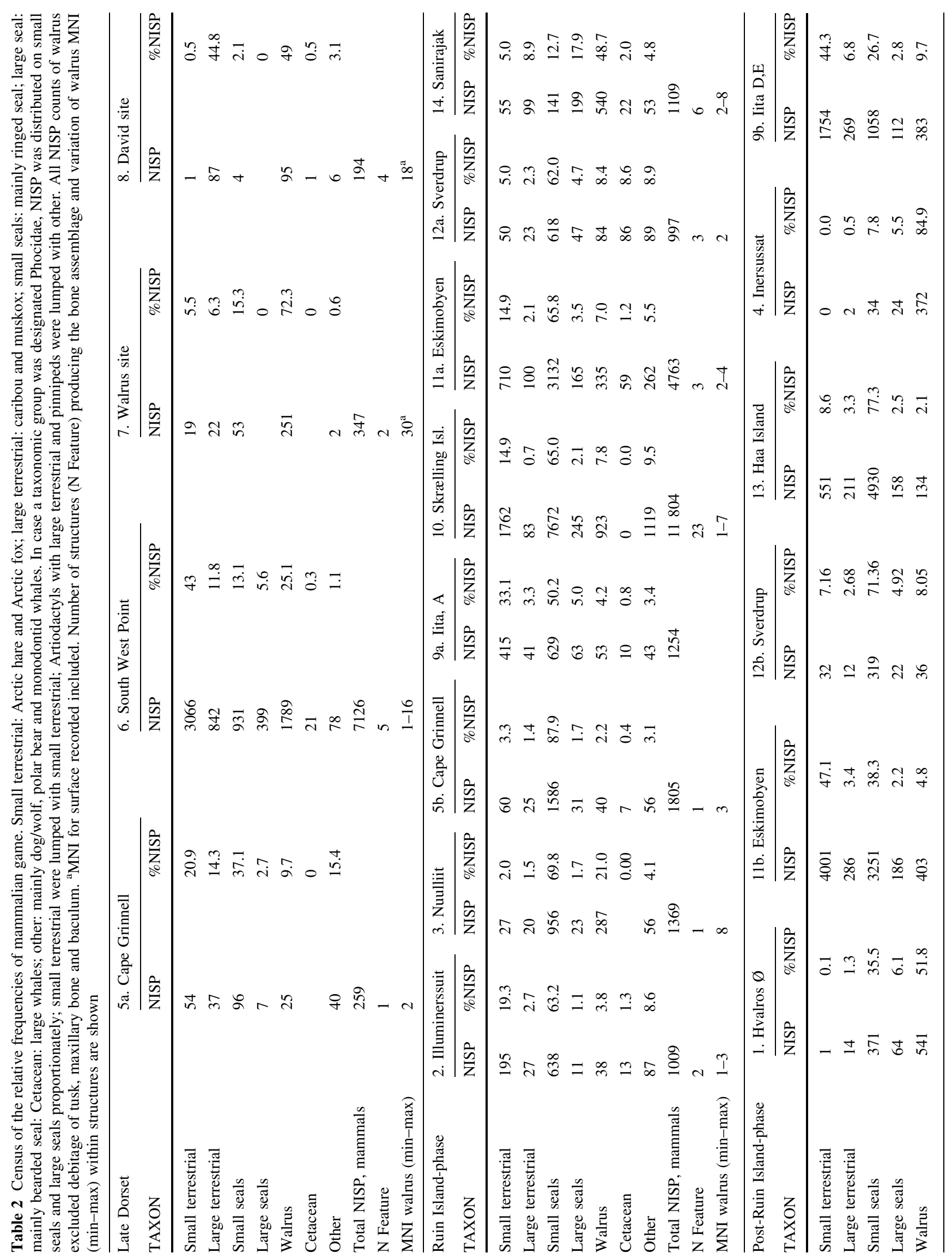




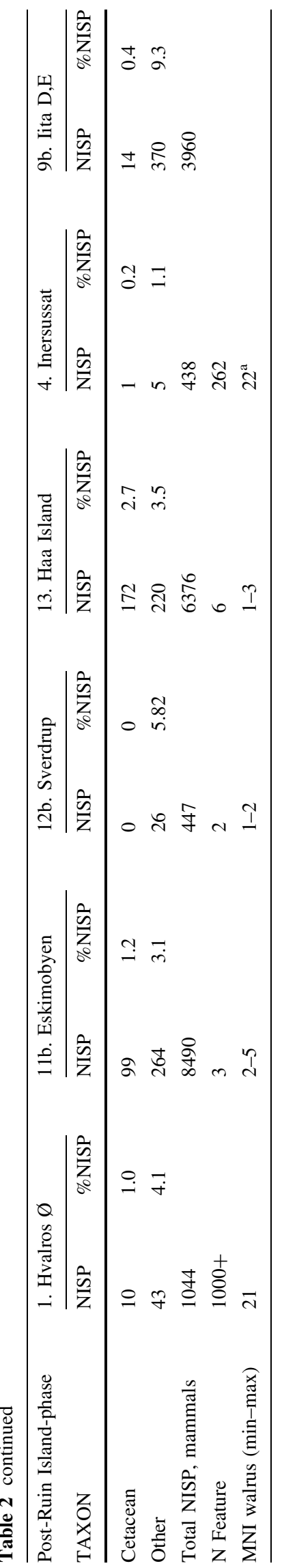

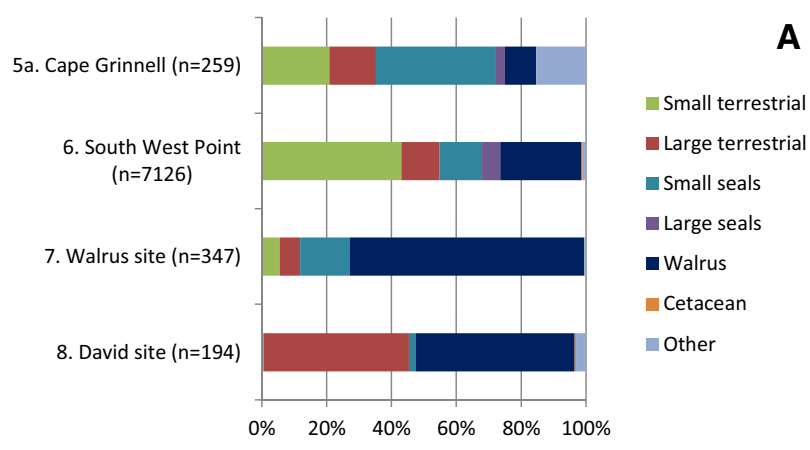

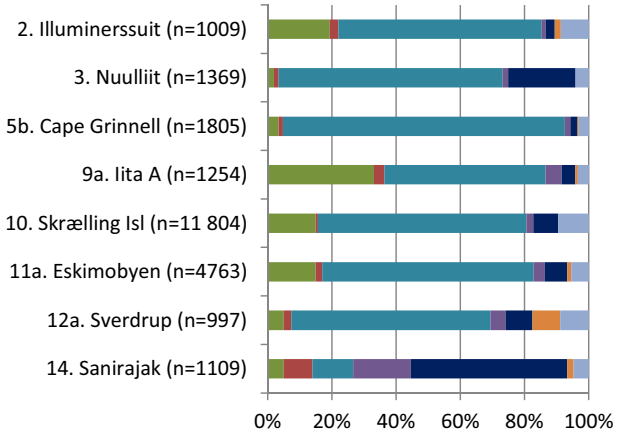

Small terrestrial

- Large terrestrial

- Smal seals

- Large seals

- Walrus

- Cetacean

Other

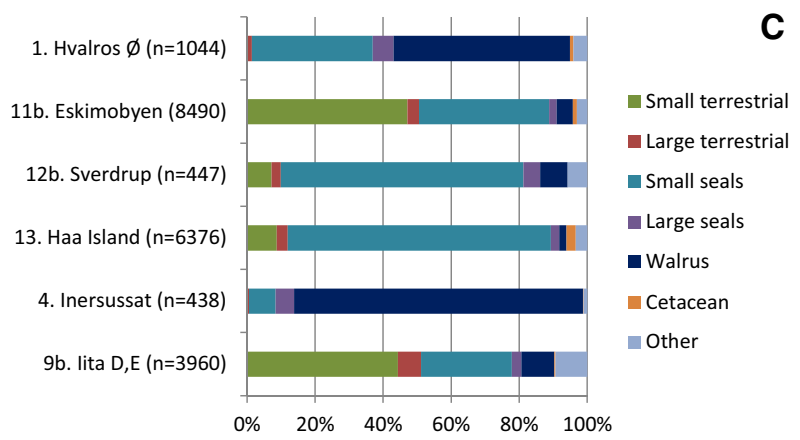

Fig. 3 Census of the relative frequencies of walrus and other mammalian game at the studied sites based on NISP (number of identified specimens) counts. a Late Dorset, b ruin Island-phase, c post-Ruin Island-phase (nos.: 1, 11b, 12b and 13) and Inughuit period (nos.: 4 and 9b). Data from Table 2

population (see Witting and Born 2014). Even if high resolution sex and age profiles based on the archaeo-zoological assemblages are difficult to obtain there are some obvious trends. The Ruin Island-phase Nuulliit qassi sample of walrus tusks, representing at least eight individuals, provided three (c. 20\%) specimens with traces of enamel still covering their tusk tip. According to King (1983) enamel caps are worn off at an age of c. 2 years, implying that in the Nulliit sample there were walrus calves caught around the time of weaning. Moreover, the historic Inughuit site Inersussat at Saundes Island provided epiphyseal fusion data indicating that slightly more than a third were hunted as juvenile or subadult (of nearly adult size) and still sexually immature walruses (Gotfredsen unpublished data). 
Table 3 Rank order of the four most common taxa of the studied sites. ${ }^{a}$ Taxonomic richness (Ntaxa) was given for mammals only

\begin{tabular}{|c|c|c|c|c|c|c|c|c|c|c|c|c|c|c|c|c|c|c|}
\hline \multirow[t]{2}{*}{ TAXA } & \multicolumn{5}{|c|}{ Late Dorset } & \multicolumn{7}{|c|}{ Ruin Island-phase } & \multicolumn{4}{|c|}{ Post-Ruin Island-phase } & \multicolumn{2}{|c|}{ Inughuit } \\
\hline & $5 a$ & $6^{\mathrm{a}}$ & $7^{\mathrm{a}}$ & $8^{\mathrm{a}}$ & 10 & 2 & 3 & $5 b$ & $9 \mathrm{a}$ & $11 \mathrm{a}$ & $12 \mathrm{a}$ & 15 & 1 & $11 \mathrm{~b}$ & $12 b$ & 13 & 4 & $9 b$ \\
\hline Small terrestrial & 2 & 1 & & & 2 & 2 & & 2 & 2 & 2 & & & & 1 & 3 & 2 & & 1 \\
\hline Large terrestrial & 3 & 3 & 2 & 3 & & & & & & & & & & & & 3 & & \\
\hline Polar bear & & & & & & & 3 & & & & & & & & & & & \\
\hline Small seals & 1 & & 3 & 2 & 1 & 1 & 1 & 1 & 1 & 1 & 1 & 3 & 2 & 2 & 1 & 1 & 2 & 2 \\
\hline Large seals & & & & & & & & & 3 & & & 2 & 3 & & & & 3 & \\
\hline Walrus & 4 & 2 & 1 & 1 & 3 & 4 & 2 & 3 & 4 & 3 & 2 & 1 & 1 & 3 & 2 & 6 & 1 & 3 \\
\hline Cetacean & & & & & & & & & & & 3 & & & & & & & \\
\hline Monodontids & & & & & & 3 & & & & & & & & & & & & \\
\hline (Ntaxa) & 14 & 12 & 7 & 7 & 23 & 10 & 16 & 13 & 16 & 21 & 15 & 12 & 14 & 14 & 11 & 12 & 12 & 17 \\
\hline NISP total & 423 & 8297 & 730 & 286 & 15237 & 2307 & 1704 & 2444 & 2084 & 5219 & 1234 & 2953 & 1174 & 15871 & 577 & 9191 & 514 & 19645 \\
\hline
\end{tabular}

A

\%NISP, Nuulliit qassi, midden

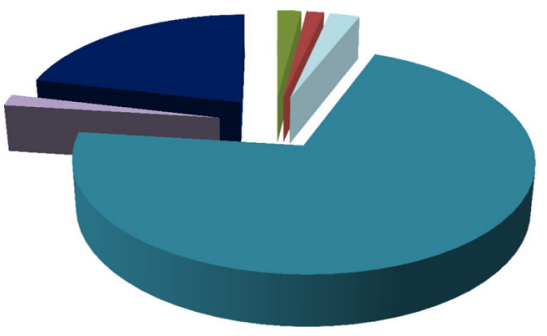

- Small terrestrial

- Large terrestrial

- Polar bear

- Ringed seal

- Bearded seal

- Walrus

B \%MNI, Nuulliit, qassi, midden

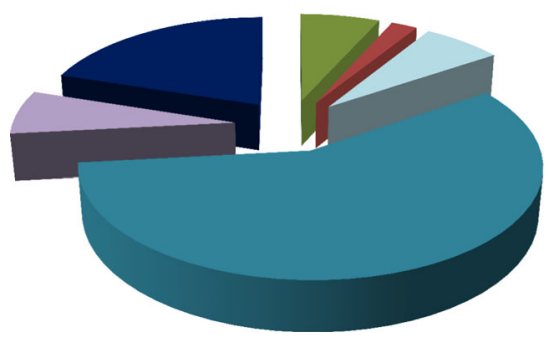

- Small terrestrial

- Large terrestrial

- Polar bear

- Ringed seal

- Bearded seal

- Walrus

C \%Biomass, Nuulliit, qassi, midden

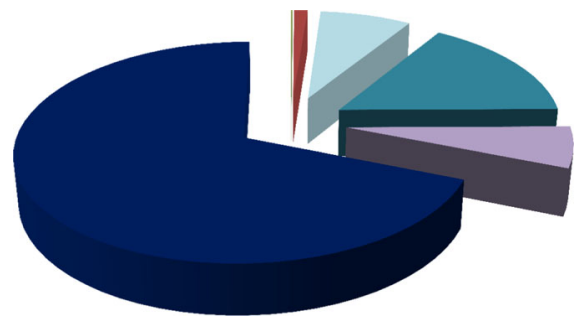

- Small terrestrial

- Large terrestrial

- Polar bear

- Ringed seal

- Bearded seal

- Walrus

Fig. 4 Census of the relative frequencies of the species identified portion of mammal bones at the Nuulliit, qassi midden. The relative importance of the various species changes dramatically whether quantified in terms of a NISP (number of identified specimens), b MNI (minimum number of individuals) and c biomass. Data from Tables 2 and 4

Walruses are characterized by a considerable sexual dimorphism, allowing sex profiles to be established by measuring relevant skeletal elements such as mandibles (e.g. Wiig et al. 2007). The measured mandibles $(n=19)$ from Inersussat showed two clusters, most likely representing females and males respectively, with females outnumbering males (Gotfredsen, unpublished data). Only two mandibles could be measured from the Nuulliit qassi midden both likely deriving from females. While limited, the biological remains suggest that all age groups and both sexes were hunted by prehistoric people (see also Monchot et al. 2013). This hunting pattern differs from the presentday situation. Especially after the introduction of quotas in 2006 the walrus catches tend to be skewed towards large adult males, providing larger amounts of meat (to feed the dog teams) and bigger trophies, although some hunters still prefer younger walruses and/or adult females due to their more tender meat (Born et al. 2017, pp. 47, 81).

Still, the mere amount of debitage at some sites, as for instance Nuulliit, where the ivory debitage comprised c. $20 \%$ and walrus bone debitage c. $7 \%$ of the total number of faunal remains, points to the importance of walrus as a source of raw material and not only edible products. Further, as seen across the material collected by Holtved during his 1947-excavation (Holtved 1954) of most of the dwellings (50+ dwelling structures) at Nuulliit $34 \%$ of all tool types involve walrus tusk, or when viewed on individual specimens 140 of $565(25 \%)$ are made of walrus tusk. At the Ruin Island-phase Inuit site Sanirajak, Desjardins (2013, p. 46) similarly reported on ivory debitage to occur abundantly through all midden layers and recovery of a large number of ivory artefacts. Already in the preInuit Dorset and Late Dorset cultures walrus tusk and bones formed an important resource for tool making often outnumbering other sources (e.g. Darwent and LeMoine 1998; Monchot et al. 2013). These finds attest to the 
Table 4 Census of mammals from Nuulliit, the qassi midden. Total body mass (TBM) average mean weights are for arctic hare from Vibe (1981), for arctic fox from Müller (1906), for polar bear and walrus from Born (1987) and for bearded seal, adult ringed seal and bowhead whale from Born and Böcher (2001, Fig. 5.124), while weights for young ringed seals are from (Smith 1973). MNI (minimum number of individuals). Data of the Nuulliit midden from Gotfredsen (unpublished)

\begin{tabular}{|c|c|c|c|c|c|c|}
\hline \multirow{2}{*}{ Taxon } & \multirow[t]{2}{*}{ Sex/age group } & \multirow[t]{2}{*}{ Total body mass (TBM) in $\mathrm{kg}$} & \multirow[t]{2}{*}{ MNI } & \multicolumn{3}{|c|}{ Excl. bowhead whale } \\
\hline & & & & $\% \mathrm{MNI}$ & Biomass & $\%$ Biomass \\
\hline Arctic fox & & 3 & 2 & 4.44 & 6 & 0.08 \\
\hline Arctic hare & & 3.55 & 1 & 2.22 & 3.55 & 0.05 \\
\hline Caribou & Average & 87.5 & 1 & 2.22 & 87.5 & 1.12 \\
\hline Polar bear & Average & 200 & 3 & 6.67 & 600 & 7.67 \\
\hline Ringed seal & Subadult & 35 & 9 & 20.00 & 315 & 4.02 \\
\hline Ringed seal & Adult, average & 55 & 17 & 37.78 & 935 & 11.95 \\
\hline Bearded seal & Average & 160 & 3 & 6.67 & 480 & 6.13 \\
\hline Walrus & Average & 600 & 9 & 20.00 & 5400 & 68.99 \\
\hline Total & & & 45 & 100 & 7827.05 & \\
\hline Bowhead whale & Average & 40000 & 1 & & & \\
\hline
\end{tabular}

significance of the walrus across cultures as a source of food for humans and dogs alike, of fuel, and of materials for the production of tools and hunting weapons.

Walrus hunting always depends on information, on available technologies (hunting tools and means of transportation), and timing, which again are connected to an entangled web of cultural historical, social, ideological and economic factors. When arriving in Avanersuaq in the 8th century $\mathrm{AD}$ the pre-Inuit Late Dorset seem to have depended on communal walrus hunting (Murray 1996; Appelt 2004) from the ice (whether on thin-ice or in ice-leads) and hunting at terrestrial haul-outs. We have no archaeological evidence of any sophicated means of transportation such as the types of vessels used later by Inuit (Appelt et al. 2016, pp. 786-787) that would have permitted open-water hunting. During the Ruin Island-phase, Inuit hunting technology included the use of both kayak and umiaq, adding open-water hunting to the range of possibilities in the region, and the use of the newly introduced dog-sledge would have made transport of people, information, and food across the region faster and more reliable.

When Europeans encountered the Inughuit living in the region in early 19 th century $\mathrm{AD}$, the use of both kayaks and umiaqs had fallen out use-not only restricting the warmseason mobility of the Inughuit communities, but also removing the possibility of open-water hunting (see e.g. LeMoine and Darwent 2016). With the arrival of a group of Baffin Islanders to Avanersuaq in the early 1860s (e.g. Mary-Rousseliere 2002) the kayak was one of the technologies that was re-introduced to the Inughuit, effectively leading to improved food security as reflected in what seems to be a rising population of Inughuit (e.g. Gilberg 1976).

\section{THE IMAGINATIVE SIGNIFICANCE OF WALRUS ACROSS CENTURIES}

In many indigenous societies across the Arctic personhood is attributed to animals (e.g. Nuttall 2000; Hill 2011). In other words animals, especially important game animals such as caribou and marine mammals, can be perceived as other-than-human-persons (Hill 2011, p. 407). The humananimal dynamics in societies that understand animals as persons are based on mutual respect and the concept of reciprocity (e.g. Fienup-Riordan 1994, pp. 58-59; Jordan 2008, pp. 236-239). Important game animals and humans were 'kinsfolk' so to say and could in many aspects behave in similar ways (Hill 2011 and references herein). The archaeological remains resulting from the human concept of human-walrus relations could be expressed in various ways. Some were listed by Hill $(2011,412 \mathrm{ff})$ from Alaska and Chukotka; comprising different kinds of amulets, large skull features with numerous walrus skulls in mounds or circles but also bone caches and 'shrines'. In the following some archaeological and ethnographic examples across cultures will be presented.

One of the key sites to our understanding of the early Inuit history in the North Water area is the abovementioned Nuulliit site. A number of unique artefacts have been excavated at the site, among which are large pieces of three gut-skin parkas (waterproof coats) from the 14th century, uncovered in House 28 (Fig. 5). They are the oldest known gut-skin clothing from the Arctic. A remarkable detail of the tailoring are the elongated wedges sewn into both the front and the back of the parkas (Holtved 1954, Figs. 49-54), which seems to be the predecessor of the socalled 'double-rooted hoods' known from 19th and 20th century parkas in Alaska and East Greenland (Hatt 1914). 


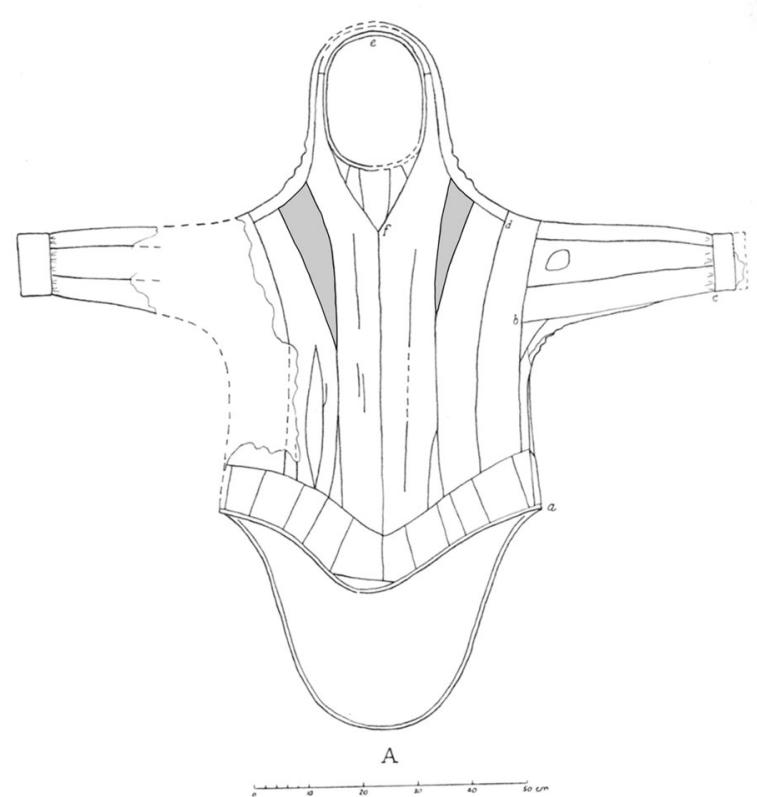

Fig. 5 One of three gut-skin parkas excavated in House 28 at the Nuulliit site modified after Holtved (1954, Fig. 49)

It has been suggested that the double-rooted hood should be seen as representing the head of the walrus with its long tusks (Schmidt et al. 2013). This particular design forms a possible point of entry into the cosmology of the Inuit world as we meet it also in stories related orally to ethnographers, missionaries and others. As Rasmussen has it: "In former times animals in human form were common... In olden times, too, everybody could easily turn into animals, and until quite recently shamans have had the same powers" (Rasmussen 1932, p. 35).

According to some of these stories the difference between humans and other living beings are shaped by the skin they wear, and in which they can take on the skin of others, as well as borrow properties from each other. When taking on the gut-skin parka, the kayaker not only had the benefit of protecting his body against the water, but also of putting on the 'walrus slough', i.e. borrowing the strength of the walrus and its ability to keep its breath for a long time under the water. Further, the walrus figures prominently in the myths and stories written down in Greenland during the 18th-early 20th century. A comprehensive archive with the 2280 online records compiled in "Sagn \& Myter" and not least an extensive introduction to this database is available (Sonne 2004a, b). Across the 116 records that make reference to walruses it is clear that they were present in diverse ways; as concrete beings of this world, as spiritual collaborators or opponents, and as emblems of particular emotions and social situations. In some of these stories (Sonne 2004a: IDs 93, 625, 795, 937, 1396, 1426) the walrus - in particular the red old, male, single and dangerous specimen (Hansen 1995) - is positioned as unpredictable and murderous; sometimes walruses are seen as brothers-in-laws or foster sons. In other stories (Sonne 2004a: IDs 126, 152, 160, 279, 340, 382, 1850) walruses are instruments of spiritual travels by lending their skin to the human actors in the stories, who may also be angakut or their apprentices. In these stories the walrus slough is referred to as a gut-skin parka, and a pooq, which again may mean 'mother', 'uterus', and 'veil of birth' in the secret language of the angakut (Sonne 2004b).

In the oral traditions of Inuit from across Greenland and across at least three centuries the walrus was of great spiritual and emblematic significance. Further, its importance is materially manifested in, among others, the 19th century East Greenlandic design of the gut-skin parkas. It thus seems reasonable to assume, by recognising the similar design manifested on the 14th century gut-skin Nuulliit parkas, that aspects of this understanding have historical roots dating back to the earliest Inuit societies in Greenland and in Alaska.

In this context, the archaeological material of the early Inuit Ruin Island-phase, a winter house-House 15 on the Skrælling Island (no. 10)_attracts particular interest. As in many similar dwellings, whalebones were used in building the floor, as well as roof support. Interestingly, House 15 had seven walrus skulls incorporated into the house back walls (Howse 2013), a construction detail occasionally seen in Late Dorset winter houses, but usually not in Inuit context. Extensive use of whalebones in the unique architectural design of early Inuit winter houses have been interpreted as a strong reference to a whale, i.e. one 'crawls inside the whale' when crawling into the house (e.g. Dawson and Levy 2006). While we cannot infer a similar interpretation of the walrus skulls in House 15 they certainly imply some cosmological connection between walrus and people during the 14th century $\mathrm{AD}$.

Moving back in time to the pre-Inuit Late Dorset culture a bell-shaped object-usually referred to as an amulet box-made from walrus tusk is of particular interest (Holtved 1944a, plate 1, 26). The box-side has five oval openings indicating eyes, nostrils and mouth, placed in a pattern indicating that the being shown is a mixture of human and animal (LeMoine et al. 1995). Similar boxsides or intact amulet boxes have been found on six other High Arctic Late Dorset sites in Arctic Canada (Appelt 2004). The top section of five of the intact amulet boxes are carved into two opposing walrus figures with interlocking tusks, in light of which it becomes obvious that the merged beings on the sides of the boxes include walrus (see Fig. 6). While carvings of human-like beings, polar bears, and bear-human figures constitute the most commonly portrayed groups of beings among the Late Dorset carvings 


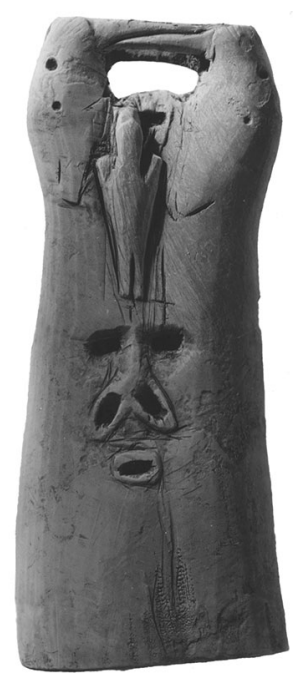

Fig. 6 A so-called 'amulet box' from the pre-Inuit late Dorset period made of walrus ivory, approximately $95 \mathrm{~mm}$ long. Notice the interlocking walrus heads at the top of the carving and the walrus/ human being at the side of the box. The amulet box is housed at the Canadian History Museum. Photo: Jørgen Meldgaard

that have so far been found in Canada and Greenland (e.g. Taçon 1985; Hardenberg 2014), the merged human-walrus beings portrayed on the amulet boxes, suggest that the walrus was an important figure in the Late Dorset cosmology.

The special position of the walrus is further underlined by a unique find from the Alarnerk site, Foxe Basin, Cental Canadian Arctic. The site is among the largest Late Dorset sites, with more than 200 dwellings including middens, of which the majority date to the late pre-Inuit period (c. 1000 BC-1200/1300 AD) (Appelt 2011). It also contains a large number of other features, among which are a number of low mounds originally identified as human burial sites (Meldgaard 1962; Lynnerup et al. 2003). One of these revealed traces of what could have been a complex series of rituals that included the incorporation of child's jawbone and a limb-bone of an adult individual. The focal interment, however, seems to have been the remains of a walrus buried with a number of grave goods, the two human bones, and what is likely to be the remains of a meal cooked upon a small fire-place, placed on top of the walrus (Odgaard 2011).

The abovementioned archaeological finds suggest that there might have been considerable differences between the Inuit and the Late Dorset communities' understanding of the specific cosmological position of walrus and in what they considered appropriate ways of maintaining these relations. Thus, the relations between humans and walruses may not only have been of even greater economic and social driver among Late Dorset groups in the North Water area and the central Canadian Arctic (Murray 1996, 1999), but also suggest that these relations were inscribed in a complex set of shamanic and shamanistic practices (LeMoine et al. 1995; Appelt et al. 2017). Whether we can establish an entire cosmology or a worldview from the known finds and observations or not, we are certainly allowed to suggest that the walrus was not only an economic resource, but also a significant source of human imagination and reflection.

\section{WALRUS HUNTING IN HISTORICAL TIMES}

Having discussed the prominent position of walrus in prehistoric economy and imagination, we now turn towards more recent times. The first Europeans making it to the Thule region in the 19th century after the receding of the Little Ice Age met a people with limited technologies but with an unquenched thirst for walrus meat (see e.g. Hayes 1867; Peary 1898). The newcomers marvelled at the hunters' skills at harpooning the huge animals from the iceedge, and the collective strength needed for dragging them onto the fast-ice or ashore (e.g. Holtved 1967).

The sea ice is still a key factor in the distribution of walrus and in the general population dynamics of the species; this is an increasing challenge, given that the High Arctic ecosystem is also subject to the major repercussions of climate change negatively affecting the walrus hunt (Born et al. 2017, p. 17). From interviews with hunters in the Thule Region, it is clear that the hunters saw "changes in walrus distribution and in the timing of their appearance in the area" (Born et al. 2017, p. 185). More specifically:

A 50-year-old informant from Qaanaaq said that because of climate warming, the sea-ice situation, and the winds, the walruses are now further away from land in October-November and are instead more out in the open sea. A hunter (aged 63) from Siorapaluk stated that the migration routes have also changed. In the 1990s the walruses moved along the coast, but nowadays they migrate farther from the coast. (Born et al. 2017, p. 185).

Other changes were mentioned in Born et al. (2017), not always consistent with each other, but still pointing to a general concern about the walrus and access to it. It is clear that whatever changes are noted, they seem to have hit the inhabitants forcefully over less than a generation, and a degree of nostalgia for past hunting feats is palpable among some of the older hunters. The hunt itself is changing shape and become increasingly individualised with the new technologies. While before, communal hunts would sometimes engage large numbers of hunters in the capture of even a single animal on thin ice (Peary 1898; Holtved 
1967), now the hunters set out in their skiffs with just one mate on board (Andersen et al. 2018).

The walrus hunt on thin-ice was the signature hunt from the 19th century until a generation ago. As vividly described by Holtved (1967, pp. 100-103), the men would go together, bringing their sledges as far out as was considered safe, and then quietly proceeding on the new ice often in a single file, until they spotted a breathing hole, in which they might hear the walrus, or notice some walruses in an opening in the ice. All hunters present would try to put their harpoons into the animal, each man immediately running back a short way on the ice with his line, and fasting it by means of the ice chisel of the lance, which is thrust down into the ice, the end loop of the line around it. The harpooned walrus would immediately go down into the water, and the hunter whose line proved to be the tautest is considered the real harpooner and receives his hunting share accordingly, i.e. first of all head, heart, and entrails (Holtved 1967, p. 102). In reading Holtved's description, one has to stretch the imagination and seek to picture the scene. For the hunters, however, all of this was part of one comprehensive action, one walrus hunt with no time to stand and ponder the next move. Evidently, the final killing and dragging up of the walrus also was a collective
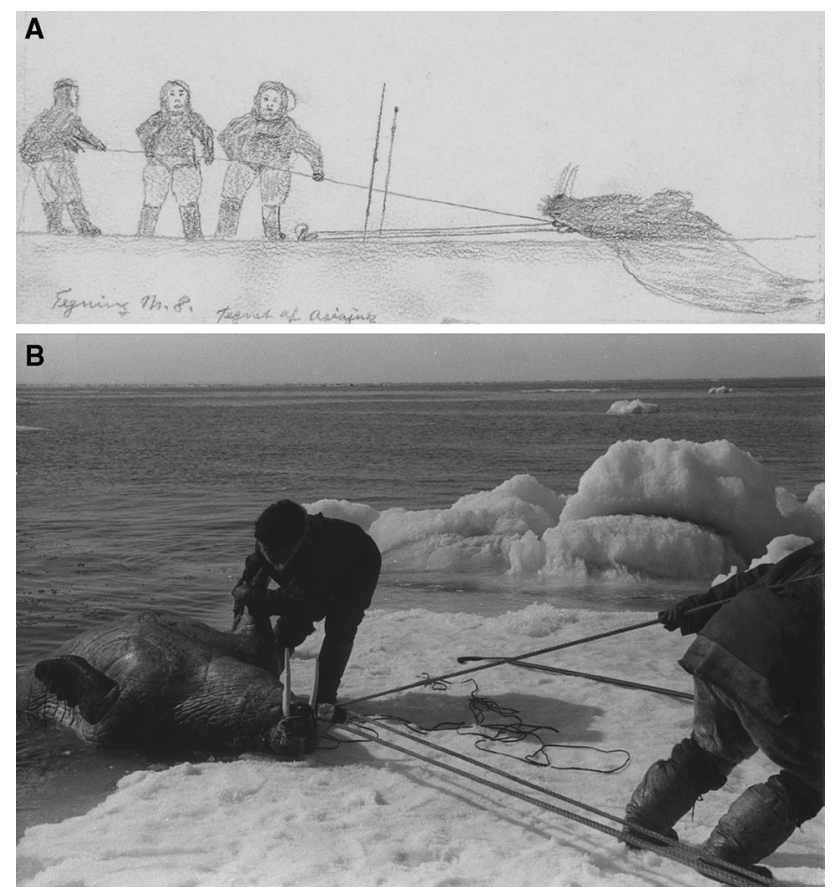

Fig. 7 a, b Walrus caught and pulled onto the Ice. Approximately 50 years and a $1000 \mathrm{~km}$ apart. The drawing was done by Asiajuk made in the region of Uummannaq (near the Thule Station) sometime between 1903 and 1920 (Strandgaard 2004). Notice the kayak parkas worn by the three hunters. Courtesy of Ilulissat Museum. The photograph was taken in 1954 in the vicinity of the Igloolik Island (Foxe Basin). The photo is housed by the National Museum of Denmark. Photo: Guy Mary-Rousseliere

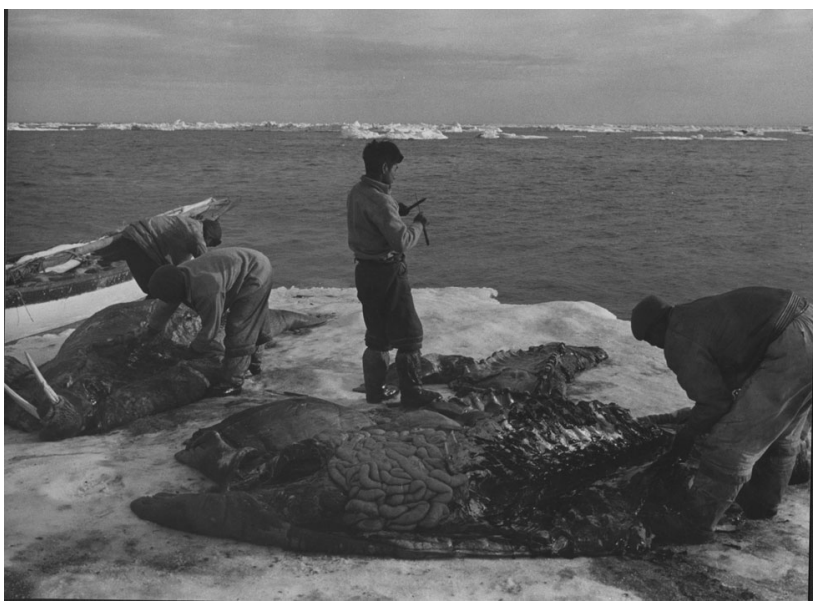

Fig. 8 Hunting walrus from ice floes. The photograph was taken in 1954 in the vicinity of the Igloolik Island (Foxe Basin). The photo is housed by the National Museum of Denmark. Photo: Guy MaryRousseliere

affair, often complicated if the ice was so thin that it was likely to break. Sometimes people would drag it under the water to a place where the ice was thicker, before attempting to drag it up see (Figs. 7a, b, 8).

Clearly, the exact timing and duration of the preferred hunting modes always depended on the ice conditions and the available hunting and transport technologies, and nowadays the spring hunt peaks already during May while the autumn hunt prevails during October-November with only some catch in September (Born et al. 2017). This is due to an earlier break-up of the ice in the spring and later ice formation in winter than just a generation ago, resulting in the walruses leaving the hunting grounds earlier and returning later from their summering grounds. The emblematic walrus hunt on thin-ice has been next to impossible due to the changing ice conditions in recent years (Born et al. 2017).

It is still vividly remembered however; thus in a conversation between an anthropologist (co-author of the present study) and a hunter just a few years ago, the latter dreamily related how 'before' they would all go to Pitoqavik (at Cape Chalon) in early winter and work like mad to get as many walruses as possible-although never on the scale described by Peary (1898, I: 421-422)—after which they would fall over in tents on the beach or the ice-foot, and he would fall asleep while others would keep recounting the high points of this particular hunt, and of many others. This storytelling seemed to have been an important part of the framing of the hunt, and European explorers were happy to contribute their stories, once they had taken part.

In Knud Rasmussen's report from the First Thule Expedition (1912-1914), there is an evocative description of a place, called Neqe, meaning 'meat', a headland close 
to Pitoqavik mentioned above. This is a very telling placename. For Rasmussen the name testified to the hunters' pragmatic sense of the good life, right here, at this spot. His description focuses on the summer hunt in the open water: "Out there, in the deceitful ocean, blood-heavy walruses swim about as the living daily bread. They populate the waters, when the brief summer loosens the binds of the ice and opens for the exciting kayak-hunt; and true to the millions of mussels at the bottom of the sea they remain over winter, so that the meat caches on land never stand empty on land" (Rasmussen 1915, pp. 14-15). He went on to describe the other advantages of this particular place, so rich in resources and always offering up multitudes of delicacies. The meat was of course the primary blessing, as transpires from the name. Walrus meat was essential not least for the dogs that could travel widely on proper feedof which walrus meat was prime.

The walrus hunting around the Thule Station (Uummannaq) in the 1930s and 1940s mainly took place on thinice with only a light snow cover, often no more than $7-8 \mathrm{~cm}$ thick, allowing the walrus to break through it at any point in time as described by Holtved and referred to above. This meant that people had to go rather a long way out towards the open water to find suitable hunting grounds at least in the vicinity of the Thule Station. Yet in other areas, notably around Neqe and Pitoqavik in the north, where Peary had his feast, the ice often broke up close to the coast during the winter storms on the edge of the North Water. After this, the sea would quickly freeze over again in the reigning cold, and Holtved noted how the people from Uummannaq and even from further south, would go up there "during March-April in order to procure meat, when their supplies have been exhausted, and live in snow houses during the time" (Holtved 1967, p. 101).

In 1930, the hunters' council introduced limitations on the hunt not only around Uummannaq but in the entire region. The council, composed of representatives from the entire region, as well as the Thule Station manager, the priest, and the doctor at Thule ruled that time had come to limit the exploitation of walrus and eiders in particular so as not to deplete the stock. "In our land, it is particularly important to protect eider ducks, arctic foxes and walruses against extinction, and any free hunter should be pleased to go along with such protective measure, because these animals otherwise would be extinct, when those people, who are children now, become adult" (Kap York Stationen Thules Love af 7. juni 1929, p. 96).

Part of the problem was the advent of rifles and the massive slaughter of walrus that occurred in the wake of 19th and early 20th century exploration in the region, severely threatening the walrus stock in Northwest Greenland, and even today-and in spite of recent protective measures-the stock is still below its historical abundance. It is recovering, however, partly in consequence of a more strict regulation, such as the quota-system introduced in 2006 , leading to a c. $30 \%$ reduction in the catch (Born et al. 2017, p. 17). Other factors may also have affected the size of walrus catches, such as a decreasing demand for walrus products, demographic changes, and changes in sea-ice cover (Born et al. 2017, pp. 7-8). Clearly, the hunters who still need a lot of meat, not least for their dogs, are affected by these factors. In the recent interview material collected by Born et al. (2017) one gets a vivid picture of the unrelenting dream of walrus on the one hand, and of the natural and political realities that puncture it on the other. The walrus hunt also still has its dangers; only a couple of years ago two hunters drowned during individual walrus hunts from their kayaks, having been tipped round by the wounded walruses; this caused a lot of local talk and also hit the national news, as witnessed by the anthropologist present. In fact, drowning was always the single most fatal occupational hazard for the Thule hunters (Gilberg 1976, pp. 27-28).

In addition to the shrinking sea ice, another effect of the general warming in the region are the ever more precarious storage facilities; until recently (and even today) people would store the surplus meat in stone caches on cool slopes, where the stone cover would protect it both from stray animals (such as foxes) and from thawing (Born et al. 2017). Now, the natural deep-freezer is increasingly unreliable, and storage becomes a serious problem. Neither this, nor the immanent dangers of the walrus-hunt at sea never made the hunters shun it. The liabilities were overruled by the need for meat, and possibly also by the need to make community 'happen'. The walrus connected people to the animals, and to each other.

\section{THE WALRUS AS A KEY SPECIES IN HUMAN HISTORY IN THE NORTH WATER AREA}

Walrus hunting was a crucial and defining activity in social life along the coasts of the North Water region during the last 1500-2000 years. The sociality among humans extended to the animals that were incorporated into human society, both literally in being eaten, and figuratively by organising communal activities and collective imageries. From the 8th century and well into the 20th century, and across different indigenous communities, archaeological and historical records alike attest to a communal organisation of the walrus hunt, and a communal distribution of the catch. Walrus was not only an important source of food for humans - and in later periods for their dog teams-it was also a crucial source of raw materials. The intensity of walrus hunting varied greatly within the region, as testified by the diversity of the studied sites, depending on the 
proximity of the site to good walrus hunting grounds and on available hunting techogies. At some sites from the early Thule period, the Ruin Island-phase, walrus ranked second to only bowhead whale in terms of providing the inhabitants with meat, blubber, and other resources. Importantly, the walrus was far more predictable than the bowhead whale, and would have been the cornerstone in the economy.

Historical sources from the 18th to the 20th century suggest that the walrus was seen as a powerful helping spirit and/or opponent, while the walrus skin was inscribed in a cosmology where the birth veils of humans, the hunting bladder, the gut-skin anorak, and the spiritual journeys of the angakok were mutually connected through shared attributes. While we cannot follow these modes of thinking about the human-animal alignment beyond the historical sources, the prehistoric traces rendered available by archaeologists strongly suggest that the walrus played a significant, if variable, role in the imagination of people across the last 2000 years at least. The idea of mutuality and human-walrus interrelatedness is still expressed among Arctic peoples e.g. the Qiqiqtamiut in southeastern Hudson Bay through the idea of all species, animals and humans, having a limited supply of souls that circulate in a closed circle of birth, death and rebirth (Guemple 1994). In such worldview, animals are finite and renewable at the same time, and among present-day Inuit and Inughuit hunters the living resources are understood as not being immediately depletable (see further discussion in Andersen et al. 2018).

While the population size, demography, and behaviour of the walrus of the North Water were markedly influenced by Europeans and eventually by Inughuit after the introduction of guns from the late 19th century onwards, the archaeological record from the North Water area gives no indication of similar effects during prehistory. Only a handful of sites exhibited high exploitation rates and, generally, prehistoric walrus hunt did probably not pose any threat to the walrus populations, although different age classes and both sexes, possibly with higher ratios of juveniles and females than presently, were targeted. Interannual and inter-decadal variability in climate resulting in variable ice coverage and storminess, and therefore variable access to the walruses most likely prevented overexploitation of the walrus stocks. Prior to the introduction of guns fewer animals were probably struck and lost because they were harpooned and secured. Still, it has been suggested that in areas with massive settlements combined with intensive exploitation some long-term depletion of stock may have occurred locally, e.g. in the Foxe Basin by Early and Middle Dorset groups (Murray 1996). In order, however, to prove such possible local effect we need archaeological faunal assemblages with a higher resolution concerning walrus demographic and skeletal profiling combined with paleo-genetic studies.

The most significant aim of this article has been to show the deep continuities between the past and present position of the walrus in the Inughuit economy and worldview. Weapons and words may have changed, but the walrus is still there, in the thick of social life in the North Water region, and as an emblem of continuity across time and space. It is in this sense that we have ventured to speak of the walrus as a 'key species'-a great practical and imaginative connector between the human and the animal world.

Acknowledgements We wish to thank our fellow NOW Project participants: Astrid O. Andersen, Thomas A. Davidson, Rune Dietz, Janne Flora, Bjarne Grønnow, Kasper Lambert Johansen, Mads Peter Heide-Jørgensen, Jens Fog Jensen, Erik Jeppesen, Anders Mosbech, Mikkel Myrup and Asta Mønsted for three inspiring fieldwork campaigns and many fruitful discussions. The NOW Project was funded by the Velux Foundations and the Carlsberg Foundation. Thanks are also due to the two reviewers for their much-appreciated suggestions and comments on this paper.

Open Access This article is distributed under the terms of the Creative Commons Attribution 4.0 International License (http:// creativecommons.org/licenses/by/4.0/), which permits unrestricted use, distribution, and reproduction in any medium, provided you give appropriate credit to the original author(s) and the source, provide a link to the Creative Commons license, and indicate if changes were made.

\section{REFERENCES}

Andersen, A.O., M.P. Heide-Jørgensen, and J. Flora. 2018. Is sustainable resource utilisation a relevant concept in Avanersuaq? The walrus case. Ambio. https://doi.org/10.1007/s13280018-1032-0.

Andersen, L.W., E.W. Born, R.E.A. Stewart, R. Dietz, D.W. Doidge, and C. Lanthier. 2014. A genetic comparison of West Greenland and Baffin Island (Canada) walruses: Management implications. NAMMCO Scientific Publications 9: 33-52. https://doi.org/10. $7557 / 3.2610$.

Appelt, M. 2004. De sidste Dorsetfolk. [The last Dorset people]. In Grønlands forhistorie [The Prehistory of Greenland], ed. H.C. Gulløv, 177-200. København: Gyldendal (in Danish).

Appelt, M. 2011. Ekspeditionerne til hvalrosfangerne i arktisk Canada [The expeditions to the walrus hunters in Arctic Canada]. Tidsskriftet Grønland 3: 219-228 (in Danish).

Appelt, M., and H.C. Gulløv. (eds.). 1999. Late Dorset in High Arctic Greenland. Final report on the Gateway to Greenland project. Copenhagen: The Danish National Museum \& Danish Polar Center.

Appelt, M., and H.C. Gulløv. 2009. Tunit, Norsemen, and Inuit in thirteen-century Northwest Greenland-Dorset between the devil and the deep sea. In The northern world AD 900-1400, ed. H. Maschner, O. Mason, and R. McGhee, 300-320. Salt Lake City: The University of Utah Press.

Appelt, M., E. Damkjar, and T.M. Friesen. 2016. Late Dorset. In The Oxford handbook of the prehistoric arctic, ed. T.M. Friesen, and O.K. Mason, 783-806. Oxford: Oxford University Press. 
Appelt, M., B. Grønnow, and U. Odgaard. 2017. Studying scale in prehistoric hunter-gatherer societies: A perspective from the eastern arctic. In Problems in Palaeolithic and Mesolithic Research, eds. M. Sørensen, and K.B. Pedersen, Arkaologiske Studier 12: 39-60.

Born, E.W. 1987. Aspects of present-day maritime subsistence hunting in the Thule area, Northwest Greenland. In Between Greenland and America. Cross cultural contact and environment in the Baffin Bay area, eds. L. Hacquebord, and R. Vaugan, 109-132. Works of the Arctic Centre no 10. Den Haag: University of Groningen. CIP-Gegevens Koninklijke Biblioteek.

Born, E.W. 2001. Reproduction in female Atlantic walruses (Odobenus rosmarus rosmarus) from northwestern Greenland. Journal of Zoology 255: 165-174.

Born, E.W. 2003. Reproduction in male Atlantic walruses (Odobenus rosmarus rosmarus) from the North Water (N Baffin Bay). Marine Mammal Science 19: 819-831.

Born, E.W. 2005. An assessment of the effects of hunting and climate on walruses in Greenland. Oslo: The Natural History Museum.

Born, E.W., M.P. Heide-Jørgensen, and R.A. Davis. 1994. The Atlantic walrus (Odobenus rosmarus rosmarus) in West Greenland. Meddelelser om Grønland, Bioscience 40: 33.

Born, E.W., I. Gjertz, and R.R. Reeves. 1995. Population assessment of Atlantic walrus (Odobenus rosmarus rosmarus L.). Oslo: Norsk Polarinstitutt, Meddelelser 138.

Born, E.W., J. Teilmann, M. Acquarone, and F. Riget. 2004. Habitat use of ringed seal (Phoca hispida) in the North Water area (North Baffin Bay). Arctic 57: 129-142.

Born, E.W., and J. Böcher (eds.). 2001. The ecology of Greenland. Nuuk: Ministry of Environment and Natural Resources. Ilinniusiorfik

Born, E.W., and M. Acquarone. 2007. An estimation of walrus (Odobenus rosmarus) predation on bivalves in the Young Sound area (NE Greenland). In Carbon cycling in Arctic marine ecosystems: Case study Young Sound, eds. S. Ryesgaard, and R.N. Glud, 176-191. Meddelelser om Grønland, Bioscience 58.

Born, E.W., A. Heilmann, L.K. Holm, K. Laidre, and M. Iversen. 2017. Walruses and the walrus hunt in West and Northwest Greenland. Monographs on Greenland, Man and Society 44. Copenhagen: Museum Tusculanum Press.

Christensen, B.B. 2000. Analysis of faunal remains from Late Dorset Paleoeskimo sites at Hatherton Bay, Inglefield Land, North Greenland. MA Thesis. Zoological Museum, University of Copenhagen.

Darwent, C.M., and J.C. Foin. 2010. Zooarchaeological analysis of a late dorset and an early Thule Dwelling at Cape Grinnell, Northwest Greenland. Journal of Geography 110: 115-336.

Darwent, C.M., and G.M. LeMoine. 1998. The walrus and the carpenter: Late Dorset Ivory working in the High Arctic. Journal of Archeological Science 25: 73-83.

Darwent, J., C. Darwent, G. LeMoine, and H. Lange. 2007. Archaeological survey of eastern Inglefield Land, Northwest Greenland. Arctic Anthropology 44: 51-86.

Darwent, J., H. Lange, G.M. LeMoine, and C.M. Darwent. 2008. The Longest Longhouse in Greenland. Antiquity 82: March 2008 Project Gallery. http://www.antiquity.ac.uk/ProjGall/darwent/ index.html.

Darwent, J., and T.B. Johansen. 2010. Archaeological survey in the foulke fjord region, Inglefield Land, Northwest Greenland. Journal of Geography 110: 297-314.

Dawson, P, and R. M. Levy. 2006. Using 3D Computer models of inuit architecture as visualizing tools in archaeological interpretation: Two case studies from the Canadian Arctic. In Dynamics of Northern Societies, eds. J. Arneborg, and B. Grønnow, 187-198. PNM-Publications from the National Museum,
Studies in Archaeology \& History 10. Copenhagen: The National Museum of Denmark.

Desjardins, S.P.A. 2013. Evidence for intensive walrus hunting by Thule Inuit, northwest Foxe Basin, Nunavut, Canada. Anthropozoologica 48: 37-51. https://doi.org/10.5252/az2013n1a2.

Dumond, D.E., and D.G. Griffin. 2002. Measurement of the marine reservoir effect on radiocarbon ages in the Eastern Bering Sea. Arctic 55: 77-86.

Dyke, A.S., J. Hooper, C.R. Harington, and J.M. Savelle. 1999. The late Wisconsinan and Holocene record of walrus (Odobenus rosmarus) from North America: A review with new data from Arctic and Atlantic Canada. Arctic 52: 160-181.

Fay, F.H. 1982. Ecology and biology of the Pacific walrus, Odobenus rosmarus divergens Illiger. Washington, DC: U.S. Fish and Wildlife Service. North American Fauna 74.

Fienup-Riordan, A. 1994. Boundaries and passages. Rule and ritual in Yup'ik Eskimo oral tradition. Norman: University of Oklahoma Press.

Freeman, M.M.R. 1975. Studies in maritime hunting II. An analysis of walrus hunting and utilization; Southampton Island, NWT. Folk 16-17: 147-158.

Freuchen, P. 1921. Om hvalrossens forekomst og vandringer ved Grønlands Vestkyst [On the distribution and migration of walruses along the western coast of Greenland]. Videnskabelige Meddelelser Dansk Naturhistorisk Forening, 72: 237-249 (in Danish).

Friesen, T.M., and O.K. Mason (eds.). 2016. The Oxford handbook of the Prehistoric Arctic. Oxford: Oxford University Press.

Garde, E., S. Jung-Madsen, S. Ditlevsen, R.G. Hansen, K.B. Zinglersen, and M.P. Heide-Jørgensen. 2018. Diving behavior of the Atlantic walrus in high arctic Greenland and Canada. Journal of Experimental Marine Biology and Ecology 500: 89-99. https://doi.org/10.1016/j.jembe.2017.12.009.

Gilberg, R. 1976. The Polar Eskimo population, Thule District, North Greenland. Meddelelser om Grønland, vol. 303, no. 3. Copenhagen: Nyt Nordisk Forlag Arnold Busck.

Gotfredsen, A.B. 2010. Faunal remains from the Wollaston ForlandClavering $\varnothing$ Region, Northeast Greenland-Thule culture subsistence in a High Arctic Polynya and Ice-edge Habitat. Geografisk Tidsskrift-Danish Journal of Geography 110: 175-200.

Grønnow, B. 2016. Living at a High Arctic Polynya: Inughuit settlement and subsistence around the North Water during the Thule Station Period, 1910-53. Arctic 69: 1-15.

Grønnow, B., H.C. Gulløv, B.H. Jakobsen, A.B. Gotfredsen, L.H. Kauffmann, A. Kroon, J.T. Pedersen, and M. Sørensen. 2011. At the edge: High Arctic walrus hunters during the Little Ice Age. Antiquity 85: 960-977.

Grønnow, B., M. Sørensen, and A.B. Gotfredsen. 2015. Arkæologiske og arkæo-zoologiske registreringer i Kap York-området, NOW projektet, 2014 [Archaeological and archaeo-zoological recordings in the Cape York area, the NOW-project, 2014]. Feltrapport 35. Sila-Arktisk center ved Etnografisk Samling, Nationalmuseet (in Danish).

Grønnow, B., M. Appelt, A.B. Gotfredsen, and M. Myrup. 2016. Arkæologiske og arkæo-zoologiske undersøgelser på bopladserne Nuulliit og Uummannaq, Avanersuaq —en del af NOW Projektet, 2015 [Archaeological and archaeo-zoological investigations on the sites Nuulliit and Uummannaq, Avanersuaq-part of the NOW Project, 2015]. Feltrapport 37. Sila-Arktisk center ved Etnografisk Samling, Nationalmuseet (in Danish).

Grønnow, B., A.B. Gotfredsen, M. Appelt, and M. Myrup. 2017. Arkæologiske registreringer, opmålinger og arkæo-zoologiske undersøgelser på Appat (Saunders $\varnothing$ ) og andre bopladser i Wolstenholme Fjord (Avanersuaq). NOW Projektet, 2016 [Archaeological recordings, surveys and, archaeo-zoological 
investigations at Appat (Saunders $\varnothing$ ) and other sites in Wolstenholme Fjord (Avanersuaq). The NOW Project, 2016]. Feltrapport 38. Sila-Arktisk center ved Etnografisk Samling, Nationalmuseet (in Danish).

Guemple, L. 1994. Born-Again Pagans: The Inuit Cycle of Spirits. In Amerindian rebirth, reincarnation belief among North American Indians and Inuit, ed. A. Mills, and R. Slobodin, 107-122. Toronto: University of Toronto Press.

Gulløv, H.C. (ed.) 2004. Grønlands forhistorie [The prehistory of Greenland]. København: Gyldendal (in Danish).

Hansen, K. 1995. Den røde hvalros—om hvalrosangreb på kajakfangere. Tidsskriftet Grønland 6: 253-260 (in Danish).

Hardenberg, M. 2014. Trends and Ontology of artistic practices of the Dorset culture $800 B C-1300 A D$. Unpublished PhD-dissertation. University of Copenhagen.

Hastrup, K., A. Mosbech, and B. Grønnow. 2018. Introducing the North Water: Histories of exploration, ice dynamics, living resources, and human settlement in the Thule Region. Ambio. https://doi.org/10.1007/s13280-018-1030-2.

Hatt, G. 1914. Arktiske Skinddragter i Eurasien og Amerika [Arctic skin suits in Eurasia and America]. Copenhagen: Græbes Bogtrykkeri (in Danish).

Hayes, E.E. 1867. The Open Polar Sea. A Narrative of a Voyage of Discovery towards the North Pole, in the Schooner "United States". London: Sampson Low, Son and Marson.

Heide-Jørgensen, M.P., M.-H.S. Sinding, N.-H. Nielsen, A. RosingAsvid, and R.G. Hansen. 2016. Large numbers of marine mammals winter in the North Water polynya. Polar Biology 39: 1-10. https://doi.org/10.1007/s00300-015-1885-7.

Hill, E. 2011. Animal as agents: Hunting ritual and relational ontologies in prehistoric Alaska and Chukotka. Cambridge Archaeological Journal 21: 407-426.

Holtved, E. 1944a. Archaeological investigations in the Thule district, I: Descriptive part. Meddelelser om Grønland 141. Copenhagen: C.A. Reitzels Forlag.

Holtved, E. 1944b. Archaeological investigations in the Thule district, II: Analytical part. Meddelelser om Grønland 141. Copenhagen: C.A. Reitzels Forlag.

Holtved, E. 1954. Archaeological investigations in the Thule District, III: Nûgdlït and Comer's Midden. Meddelelser om Grønland 146. Copenhagen: C.A. Reitzels Forlag.

Holtved, E. 1967. Contributions to Polar Eskimo Ethnography. Meddelelser om Grønland 182(2) Copenhagen: C.A. Reitzels Forlag.

Howse, L. 2013. Revisiting an early Thule Inuit occupation of Skraeling Island, Canadian High Arctic. Études/Inuit/Studies 37: $103-125$.

Johansen, T.B. 2013. Foraging efficiency and small game: The importance of Dovekie (Alle alle) in Inughuit subsistence. Archaeozoologica 48: 75-88.

Jordan, P. 2008. Northern landscapes, northern mind: on the trail of an 'archaeological hunter-gatherer belief'. In Belief in the past: Theoretical approaches to the archaeology of religion, ed. D.S. Whitley, and K. Hays-Gilpin, 17-45. Walnut creek: Left Coast Press.

Kap York Stationen Thules Love af 7. juni 1929. Kundgørelser vedrørende Grønlands Styrelse nr. 2. 1947, pp. 91-111. (in Danish).

King, J.E. 1983. Seals of the world, 240. Oxford: Oxford University Press.

Knutsen, K., and E.W. Born. 1994. Body growth in Atlantic walruses (Odobenus rosmarus rosmarus) from Greenland. Journal of Zoology 234: 371-385.

Kovacs, K.M., J. Aars, and C. Lydersen. 2014. Walruses recovering after $60+$ years of protection in Svalbard, Norway. Research
Note. Polar Research 33: 26034. https://doi.org/10.3402/polar. v33.26034.

Laidre, K.L., I. Stirling, L.F. Lowry, M.P. Heide-Jørgensen, and S.H. Ferguson. 2008. Quantifying the sensitivity of arctic mammals to climate-induced climate change. Ecological Applications 18: $97-125$.

LeMoine, G.M., and C.M. Darwent. 2010. The Inglefield Land archaeology project: Introduction and overview. Journal of Geography 110: 279-296.

LeMoine, G.M., and C.M. Darwent. 2016. Development of Polar Inughuit culture in the Smith sound region. In The Oxford handbook of the prehistoric arctic, ed. T.M. Friesen, and O.K. Mason, 873-896. Oxford: Oxford University Press.

LeMoine, G.M., J. Helmer, and D. Hanne. 1995. Altered states: Human-Animal transformational images in Dorset Art. In The symbolic role of animals in archaeology, eds. K. Ryan, and P.J. Crabtree, 38-49. MASCA, University of Pennsylvania Museum of Archaeology and Anthropology 12.

Lyman, R.L. 1996. Vertebrate taphonomy. Cambridge: Cambridge University Press.

Lynnerup, N., J. Meldgaard, J. Jakobsen, M. Appelt, A. Koch, and R. Frøhlich. 2003. Human Dorset remains from Igloolik Canada. Arctic 56: 349-358.

Maanasa, R., M. DeGiorgio, A. Albrechtsen, I. Moltke, P. Skoglund, T.S. Korneliussen, B. Grønnow, M. Appelt, et al. 2014. The genetic prehistory of the new world arctic. Science 345: 1255832

McCullough, K.M. 1989. The ruin islanders. Early Thule pioneers in the eastern High Arctic. Ottawa: National Museums of Canada, Mercury Series 141.

Meldgaard, J. 1962. On the formative period of the Dorset culture. In Prehistoric cultural relations between the arctic and temperate zones of North America, ed. J.M. Campbell, 92-95. Arctic Institute of North America, Technical Paper 11.

Mary-Rousseliere, G., 2002. Qillarsuaq. Nunat issitttut inuisa ingerlaarnerannik oqaluttaq/Beretning om en arktisk folkevandring/ Bericht über eine arktische Völkerwanderung. Specialtrykkeriet Viborg: Atuagkat.

Monchot, H., C. Houmard, M.-M. Dionne, P.M. Desrosiers, and D. Gendron. 2013. The modus operandi of walrus exploitation during the Palaeoeskimo period at the Tayra site, Arctic Canada. Anthropozoologica 48: 15-36. https://doi.org/10.5252/ az2013n1a1.

Murray, M.S. 1996. Economic change in the Palaeoeskimo prehistory of the Foxe Basin, NWT. Unpublished PhD-dissertation. Hamilton: McMaster University.

Murray, M.S. 1999. Local heroes. The long-term effects of short-term prosperity-An example from Canadian Arctic. World Archaeology 30: 366-483.

Müller, R. 1906. Vildtet og jagten i Sydgrønland [The game and the hunt in South Greenland]. København: Universitetets Bogtrykkeri, 1-519 (in Danish).

Mønsted, A. 2016. Mandshuset på Nuulliit: Etnografisk-arkæologisk analyse af et qassi i det nordlige Grønland [The Men's house at Nuulliit: An ethnographic-archaeological analysis of a qassi in northern Greenland]. Unpublished MA-dissertation from University of Copenhagen (in Danish).

NAMMCO. 2006. NAMMCO annual report 2005. Tromsø: North Atlantic Marine Mammal Commission.

NAMMCO. 2010. NAMMCO annual report 2010. Tromsø: North Atlantic Marine Mammal Commission.

Nelson, R.K. 1969. Hunters of the northern ice. Chicago: The University of Chicago Press.

Nuttall, M. 2000. Becoming a hunter in Greenland. Etude/Inuit/ Studies 24: 33-45. 
Odgaard, U. 2011. Memory of a myth-A unique Late Dorset ritual structure. In Northern world-Challenges and solutions, ed. H.C. Gulløv, P.A. Toft, and C.P. Hansgaard, 247-260. Copenhagen: Nationalmuseet.

Peary, R.E. 1898. Northward over the great ice, vol. I \& II. London: Methuen \& Co.

Peary, R.E. 1917. Secrets of Polar Travel. New York: The Century Co.

Rasmussen, K. 1915. Min Rejsedagbog. Skildringer fra den første Thule-Ekspedition, København: Gyldendalske Boghandel, Nordisk Forlag (in Danish)

Rasmussen, K. 1932. Intellectual culture of the Copper Eskimos. Report of the Fifth Thule Expedition 1921-24. Copenhagen: Nordisk Forlag.

Savelle, J. 2002. The Umialiit-Kariyit whaling complex and prehistoric Thule Eskimo social relations in the Eastern Canadian Arctic. Bulletin of National Museum of Ethnology 27: 159-188.

Schledermann, P. 1990. Crossroads to Greenland: 3000 years of prehistory in the Eastern High Arctic. Komatic Series 2. Calgary: The Arctic Institute of North America of the University of Calgary.

Schledermann, P. 1996. Voices in Stone. A personal Journey into the Arctic Past. Komatik Series 5. The Arctic Institute of North America of the University of Calgary.

Schledermann, P., and K.M. McCullough. 2003. Late Thule culture developments on the central East Coast of Ellesmere Island. Copenhagen: The Danish National Museum \& Danish Polar Center.

Schmidt, A.-L., B. Gottlieb, H.C. Gulløv, C. Jensen, and A.H. Petersen. 2013. Pelse fra Nord [Furs from the North]. Nationalmuseets Arbejdsmark, 64-79 (in Danish).

Smith, T.G. 1973. Population dynamics of the ringed seal in the Canadian eastern arctic. Fisheries Research Board of Canada Bulletin 181: 1-55.

Sonne, B. 2004a. Grønlandske sagn \& myter/Sonnes base [Greenlandic legends \& myths/Sonne's database]. http://arktiskinstitut. $\mathrm{dk} /$ vidensdatabaserne/groenlandske-sagn-myter-sonnes-base/.

Sonne, B. 2004b. Vejledning og introduktion til Grønlandske sagn \& myter [Guide and introduction to Greenlandic legends \& myths]. http://arktiskinstitut.dk/vidensdatabaserne/groenlandske-sagnmyter-sonnes-base/.

Stewart, R.E.A., E.W. Born, R. Dietz, M.P. Heide-Jørgensen, F.F. Rigét, K. Laidre, M.V. Jensen, L.Ø. Knutsen, et al. 2014. Abundance of Atlantic walrus in western Nares Strait, Baffin Bay stock, during summer. NAMMCO Scientific Publications 9: 123-140. https://doi.org/10.7557/3.2611.

Strandgaard, K. 2004. Titartaanersuavik - Inughuit titartaqqaataat. Knud Rasmussenimit katersorneqarsimasut 1903-1920/Et sandt tegneraseri - Inughuit's forste tegninger. Indsamlet af Knud Rasmussen 1903-1920/A Passion for Drawing - The first drawings made by Inughuit. Collected by Knud Rasmussen 1903-1920. Nuuk: Atuagkat. 171 pp.

Stuiver, M., and P.J. Reimer. 1993. Extended ${ }^{14} \mathrm{C}$ data base and revised CALIB $3.0{ }^{14} \mathrm{C}$ calibration program. Radiocarbon 35 : $215-230$.
Sørensen, M. 2010. The archaeology of old Nuulliit: Eigil Knuth's investigations in the Thule region, North Greenland, from 1952 to 1990. Meddelelser om Grønland/Monographs on Greenland 349. Copenhagen: Tusculanum Press.

Sørensen, M., and H.C. Gulløv. 2012. The prehistory of Inuit in Northeast Greenland. Arctic Anthropology 49: 88-104.

Taçon, P.S.C. 1985. An analysis of Dorset Art in relation to prehistoric culture stress. Études/Inuit/Studies 7: 41-65.

Vibe, C. 1950. The Marine Mammals and the Marine Fauna in the Thule district (North West Greenland) with Observations of the Ice Conditions in the 1939-41. Meddelelser om Grønland 150.

Vibe, C. 1981. Pattedyr (Mammalia) [Mammals (Mammalia)] In Grønlands Fauna [The Fauna of Greenland], ed. F. Salomonsen, 363-459. Gyldendalske Boghandel, Nordisk Forlag (in Danish).

Wiig, Ø., E.W. Born, I. Gjertz, C. Lydersen, and R.E.A. Stewart. 2007. Historical sex-specific distribution of Atlantic walrus (Odobenus rosmarus rosmarus) in Svalbard assessed by mandible measurements. Polar Biology 31: 69-75. https://doi. org/10.1007/s00300-007-0334-7.

Witting, L., and E.W. Born. 2014. Population dynamics of walrus in Greenland. NAMMCO Scientific Publications 9: 191-218. https://doi.org/10.7557/3.2612.

Woollet, J.M., A. Henshaw, and C.P. Wake. 2000. Palaeoecological implications of archaeological seal bone assemblages: Case studies from labrador and Baffin Island. Arctic 53: 395-423.

\section{AUTHOR BIOGRAPHIES}

Anne Birgitte Gotfredsen $(\bowtie)$ Ph.D., is research associate at the Natural History Museum of Denmark, University of Copenhagen. Her research includes Arctic environmental history, marine mammal resource dynamics and human adaptation through time, based on archaeo-zoological evidence.

Address: Natural History Museum of Denmark, University of Copenhagen, Øster Voldgade 5-7, 1350 Copenhagen, Denmark. e-mail: abgotfreds@snm.ku.dk

Martin Appelt Ph.D., is curator and senior researcher at the Department of Modern History and World Cultures at the National Museum of Denmark. His research interests include Eastern Arctic prehistory, in particular Late Dorset and Thule Culture.

Address: The National Museum of Denmark, Frederiksholms Kanal 12, 1220 Copenhagen, Denmark.

e-mail: martin.appelt@natmus.dk

Kirsten Hastrup D.Phil, \& dr.scient.soc. is Professor of Anthropology at University of Copenhagen. Her research interests centre on the interface between natural and social histories in the North. She has done fieldwork first in Iceland, and over the past decade in the Thule Region in Greenland.

Address: Department of Anthropology, University of Copenhagen, Øster Farimagsgade 5, 1353 Copenhagen, Denmark.

e-mail: Kirsten.hastrup@anthro.ku.dk 